
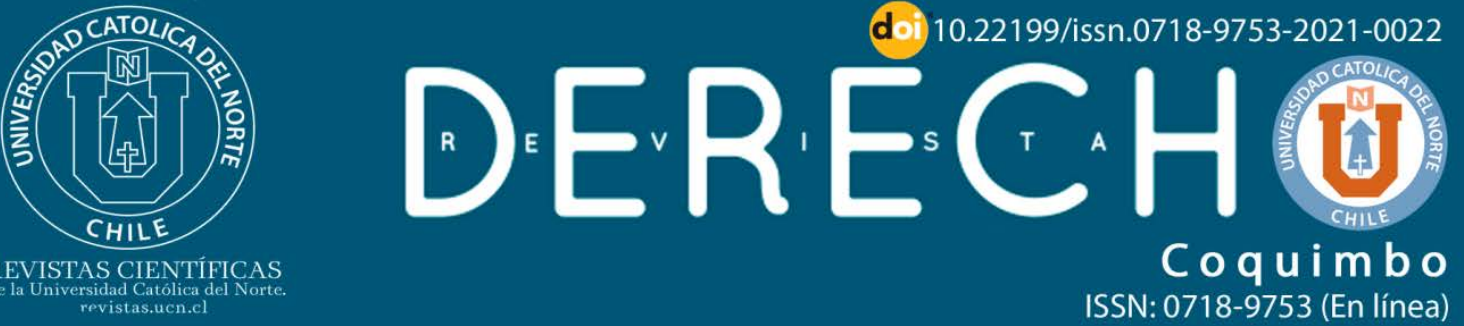

\title{
Reformas al régimen patrimonial de la Iglesia Católica sugeridas desde España y Latinoamérica al iniciarse la codificación del derecho canónico de 1917.
}

\section{Reforms to the patrimonial regime of the Catholic Church suggested from Spain and Latin America at the beginning of the 1917 codifica- tion of canon law.}

\section{Carlos Salinas Araneda ${ }^{1}$}

1Pontificia Universidad Católica de Valparaíso, Valparaíso, Chile. Facultad de Derecho. Doctor en Derecho, U. Complutense, España, Doctor en Derecho Canónico, Pontificia Università di San Tommaso d'Aquino (Angelicum), Italia. carlos.salinas@pucv.cl

\section{Resumen:}

Se estudian las propuestas formuladas en 1904 por los obispos españoles y latinoamericanos postulata episcoporum - al iniciarse la codificación del derecho canónico de 1917, ordenada por el papa Pío X mediante el motu proprio denominado Arduum sane munus, sugiriendo reformas al régimen patrimonial de la Iglesia, en respuesta a la consulta hecha desde Roma por la Secretaría de Estado de la Santa Sede, mediante Ia circular Litterae circulares ad omnes Episcopos pro Ecclesiae legibus in unum redigendis. Estas propuestas permiten percibir los problemas que, en materia de bienes, tenían los obispos hispano-americanos en sus iglesias particulares. Se ofrece una visión de conjunto de los aportes arribados a Roma desde las iglesias hispanoparlantes en materia de bienes eclesiásticos.

Palabras Clave: Bienes eclesiásticos; Codex iuris canonici (1917); Postulata episcoporum; Obispos españoles; Obispos latinoamericanos.

\begin{abstract}
:
The proposals developed in 1904 by the Spanish and Latin-American bishops -postulata episcoporum- at the beginning of the 1917 codification of canon law, ordered by pope Pius $X$ in motu proprio Arduum sane munus, suggesting reforms to the patrimonial regime of the Church, in response to the consultation made from Rome, by the Holy See Secretary of State in circular letter Litterae circulares ad omnes Episcopos pro Ecclesiae legibus in unum redigendis, are studied. These proposals allow to appreciate the problems that, in terms of assets, the HispanicAmerican bishops had in their particular churches. An overview of the contributions received in Rome from the Spanish-speaking churches regarding ecclesiastical assets is presented.

Keywords: Ecclesiastical assets; Codex iuris canonici (1917); Postulata episcoporum; Spanish bishops; Latin-American bishops
\end{abstract}


Reformas al régimen patrimonial de la Iglesia Católica sugeridas desde España...

\section{Introducción}

La tarea de confeccionar un Codex luris Canonici (1917) que sustituyera al Corpus luris Canonici de 1879, fue iniciada por Pío X (1903-1914) poco después de haber iniciado su pontificado, en los albores del siglo XX, mediante el motu proprio Arduum sane munus, de 14 de abril de 1904, con el cual creó una comisión pontificia encargada de asumir la codificación del derecho de la Iglesia. El mismo motu proprio dispuso la intervención en esta obra de todo el episcopado latino, la que se puso en práctica mediante una carta circular firmada por el Cardenal Merry del Val (con fecha 25 de marzo de 1904), y enviada a todos los metropolitanos. En ella se pedía que los arzobispos, oyendo previamente a sus obispos sufragáneos y otros ordinarios que debían estar presente en el concilio provincial, enviaren a la Santa Sede, dentro de los cuatro meses siguientes, en pocas palabras, las principales modificaciones y correcciones que debían hacerse al derecho canónico en vigor. En la misma circular se indicaba que era deseo formal del papa ver a todo el episcopado concurrir y tomar parte activa en un asunto que interesaba en grado máximo el bien y utilidad de toda la Iglesia católica. Detrás de esta segunda decisión se puede ver el interés del papa de que participaran en la nueva fijación del derecho de la Iglesia, no sólo especialistas en cánones o en teología, sino que también los hombres prácticos que cotidianamente debían trabajar con los cánones en el gobierno de sus iglesias particulares (Vetulani, 1942, p. 920). La respuesta de los obispos de la iglesia latina fue amplia, contándose entre ellas la de los obispos españoles y latinoamericanos y en ellos se refleja el sentir del episcopado mundial en lo que se refiere a la codificación y permiten conocer cuales eran las preocupaciones y los problemas que interesaban al episcopado mundial a los inicios del siglo XX, no sólo de orden jurídico, sino también en otras dimensiones del actuar eclesial como disciplinar, pastoral u otras y en ellos se solicitaron soluciones que, en no pocos casos, sólo fueron adoptadas por el Concilio Vaticano Il y el Código de Derecho Canónico de 1983.

\section{Propuestas de reforma del régimen de bienes de la Iglesia}

La Iglesia fundada por Jesucristo es una sociedad perfecta, externa, visible, la cual es rejida i gobernada por sus pastores, i profesa i ejerce un culto externo. Una sociedad tal no puede subsistir ni llenar los fines de su institución, a menos que posea bienes i derechos útiles con que pueda proveer a los gastos i expensas que le son necesarios. Así es que el mismo Cristo, de quien recibió su réjimen, le concedió la capacidad necesaria para adquirir bienes, i tener en ellos verdadero dominio; cuya capacidad no emana por consiguiente de concesiones de los príncipes. (Donoso Vivanco, 1849, p. 275)

En estos términos, Donoso Vivanco (1849), haciendo uso de la terminología propia de la época en que escribía, se refería a la capacidad que tiene la Iglesia de 
adquirir, retener, administrar y enajenar bienes para poder llevar a cumplimiento la tarea que le encomendó su Fundador. Siendo la materia patrimonial un aspecto de importancia en el actuar eclesial, los prelados consultados tanto en España como en América la abordaron, haciendo propuestas concretas en orden a perfeccionar el régimen de bienes de la Iglesia en el Código que se preparaba. Son los postulata que abordo a continuación, a los que agrego una breve referencia a la disciplina finalmente sancionada en el Codex luris Canonici (1917).

\subsection{Beneficios eclesiásticos}

Hay en las propuestas arribadas a Roma desde Hispanoamérica diversas sugerencias de reformas al régimen beneficial, que era el sistema que había desarrollado la Iglesia, a partir de la Edad Media, para sustentar económicamente a quienes se dedicaban a las labores eclesiales.

El nombre Beneficio significa en su orijen el predio fiscal que los emperadores romanos solían dar a los gefes i soldados beneméritos que se distinguían en la defensa del Estado, para que así pudieran proporcionarse, en su retiro i en la ancianidad, una conveniente subsistencia. A este ejemplo la Iglesia comenzó a distribuir predios a los clérigos beneméritos para que se alimentasen con sus producciones; i estos predios se llamaron beneficios, i los clérigos que los obtenían beneficiados. (Donoso Vivanco, 1849 , p. 290)

La palabra beneficio, en el sentido con que se utilizaba a principios del siglo XX, se había usado ya en el siglo VIII, en el Concilio de Frankfort de 794 y en el Concilio de Macon de 813 y era definido en España por Gómez Salazar (1883), poco antes de iniciarse la codificación, como "El derecho perpetuo a percibir las rentas de los bienes eclesiásticos por algún servicio espiritual constituido por la autoridad eclesiástica" (p. 417). Se trataba de un régimen consolidado, por lo que ninguna de las sugerencias referidas a ellos lo pusieron en cuestión: sólo se limitaron a algunos aspectos particulares del sistema. La definitiva sustitución del mismo vendría con el Concilio Vaticano Il (1962-1965) y el Código de Derecho Canónico de 1983.

\subsubsection{Provisión de beneficios eclesiásticos}

Había dispuesto el Concilio de Trento (Iglesia Católica, 1563, cap. 18) que, para la provisión de parroquias vacantes, los candidatos a las mismas debieran someterse a un examen ante tres examinadores diocesanos quienes, terminado el examen, “...darán nota de todos los que han encontrado aptos por su edad, costumbres, ciencia, prudencia y demás condiciones que se requieren para gobernar la iglesia vacante ; y de estos elegirá el obispo al que considere más idóneo que los demás" (Esquivel, 1928, p. 280). Por decreto de la Sagrada Congregación del Concilio, de 10 enero 1721, confirmado por Clemente $\mathrm{XI}$, se establecieron las normas que regulaban el desarrollo de los exámenes. Citado en Gómez Salazar (1883, pp. 490-491). 
Reformas al régimen patrimonial de la Iglesia Católica sugeridas desde España...

Parece que estas exigencias se habían diluido algo en Ecuador, pues el arzobispo de Quito (Commissione Codice di Diritto Canonico, s.f.g, 8) pedía que se mantuviese en su primer rigor la ley de concurso con todas las reglas, circunstancias y previsiones del derecho, para la provisión de beneficios, así como las exigencias referidas a la privación, resignación y permutación de los mismos.

En cambio, las circunstancias complejas por las que atravesaba la Iglesia en México desde el siglo anterior, hacían que el arzobispo de Durango propusiera precisamente lo contrario. Según este prelado, las peores circunstancias de cambio de tiempo y lugares habían originado grandes dificultades en la observancia de dicha ley, principalmente por la escasez de sacerdotes, a partir de la cual ocurría que quienes proseguían la celebración del concurso, abandonaban las parroquias, ausencia que no podía ser sustituida, de lo que venía grave detrimento de las almas. Del mismo modo, la experiencia mostraba que las envidias y las murmuraciones contra los superiores que hacían aquellos que habían sido vencidos en el concurso, sintiéndose rechazados y pospuestos por menos dignos, a veces -lo que debe doler más, agregaba el prelado- llegaban a ser públicas, de lo que surgía el escándalo, rompiéndose los vínculos de paz entre superiores e inferiores. A lo anterior se agregaba la inicua condición de las leyes civiles que negaban toda protección a la Iglesia, por lo que, apelando a la costumbre que existía en otros lugares, entendía que parecía conveniente "que en estos luctuosos tiempos" la ley del concurso no estuviere vigente (Commissione Codice di Diritto Canonico, s.f.c, 8).

En una postura más bien intermedia, los metropolitanos españoles (Commissione Codice di Diritto Canonico, s.f.l) pedían mayor libertad del obispo para los beneficios parroquiales, pues entendían ellos que había suma necesidad de que los beneficios parroquiales estuvieren adscritos a la libre disposición del obispo o, al menos, si existían inmuebles, se entregaren a los obispos mayores facultades de las que hasta ese momento disponían, para que, existiendo causas justas, pudieren trasladar al párroco propio, incluso contra su voluntad, a otro beneficio y asimismo privarlo de su propia parroquia.

"Debemos reconocer que es negocio arduo el formar juicio exacto acerca de quién posee todas las cualidades requeridas para gobernar con fruto una parroquia" (Cabreros de Anta et al., 1963, p. 730), razón por la que el tridentino, como lo he señalado, había introducido el sistema de concurso especial el que, en varias regiones incluida España, se había convertido en concurso general; pero, como no era fácil en todas partes valerse del concurso, la Santa Sede se había mostrado tolerante, permitiendo a los obispos que procedieran de otro modo. El Codex (1917) conservó la exigencia del concurso, disponiendo que se sometiera al clérigo a un examen doctrinal en presencia del obispo y de los examinadores sinodales, pero permitió la dispensa de este examen con el consentimiento de los examinadores, "cuando se trate de un 
sacerdote recomendable por sus conocimientos teológicos" (Codex luris Canonici, 1917, can. 459,§ 3, n³).

Pedían los metropolitanos españoles que, existiendo causas justas, pudieren trasladar -se trata de trasladar no de remover- al párroco propio, incluso contra su voluntad, a otro beneficio y asimismo privarlo de su propia parroquia, petición de mayores facultades basada en el hecho de que en España (García Barberena, 1964, p. 122) todas las parroquias eran inamovibles, los que eran puestos al frente de una parroquia para administrarla como rectores propios debían ser estables en ella; pero no todos los párrocos adquirían la misma estabilidad: los que gozaban de mayor, solían llamarse inamovibles; los de menor, amovibles. Pero esto no quitaba que pudieren ser removidos conforme a derecho (Codex luris Canonici, 1917, can. 454). El Codex dedicó un título completo del Libro IV al "modo de proceder en el traslado de párrocos" (Codex luris Canonici, 1917, cann. 2162-2167), disponiendo que el ordinario no podía trasladar contra su voluntad al párroco inamovible si no había obtenido facultades especiales de la Sede Apostólica (Codex luris Canonici, 1917, can. 2163, § 1); pero, tratándose de párrocos amovibles, si la parroquia ad quem no era de categoría demasiado inferior, podía trasladarlo aun contra su voluntad, observando el procedimiento regulado en dichos cánones (Codex luris Canonici, 1917, can. 2163, § 2). Pero los metropolitanos españoles pedían, además, mayor libertad para privar a un párroco de su parroquia, lo que nos sitúa en la posibilidad de la remoción, que es diversa del traslado: en aquella se trata de un párroco que, con culpa o sin ella, es dañoso o al menos ineficaz en la parroquia que regenta, por lo que se le destituye y se le envía a otro puesto; en el traslado, en cambio, se trata de un párroco que gobierna fructuosamente su parroquia, por lo que es trasladado a otra parroquia de mayor dificultad por el bien de las almas. También el Codex dedicó dos títulos del Libro IV a esta materia, en los que reguló el "modo de proceder en la remoción de los párrocos inamovibles" (Codex luris Canonici, 1917, cann. 2147-2156) y el "modo de proceder en la remisión de los párrocos amovibles" (Codex luris Canonici, 1917, cann. 2157-2161). Una de las causas para proceder a la remoción de un párroco inamovible era "la mala administración de los bienes temporales" (Codex luris Canonici, 1917, can. $\left.2147, \S 2, n^{\circ} 5\right)$, que era la idea que, al parecer, subyacía en la propuesta hispana.

En esta materia, el Codex (1917) recogió lo que la Sacra Congregatio Consistorial había regulado en el decreto De amotione administrata ab officio et beneficio curato, de 20 de agosto de 1910 (Cardenal Scipione Tecchi, 1910), dictado algunos años después que los metropolitanos españoles hicieran su postulatum, el que, al menos en parte, ya se había visto acogido en dicho decreto. Se dio mayores márgenes de acción al obispo, pero no la libre disposición que pedían los arzobispos desde España. 
Reformas al régimen patrimonial de la Iglesia Católica sugeridas desde España...

\subsubsection{Título eclesiástico para recibir las órdenes sagradas}

Para la recepción del orden sacro, requería el derecho canónico un título eclesiástico o clerical, que no era sino "...que la cantidad de bienes temporales suficiente para la congrua sustentación del clérigo..." (Donoso Vivanco, 1849, p. 122), lo que se exigía para "...que el ministro de la relijion no se vea obligado cum ordinis dedecore mendicare, aut sordidum aliquem quaestum exercere. Por congrua sustentación entiendese principalmente, el alimento, el vestido i la habitación..." (Donoso Vivanco, 1849, p. 122); como las expensas para ello variaban según las circunstancias de tiempo, lugar o personas, se dejaba a la discreción de los obispos la fijación de la suma a que, en sus diócesis, debían ascender las producciones del título clerical.

El título de ordenación podía ser: i) de beneficio, ii) de patrimonio, iii) de pobreza religiosa y iv) de servicio de la Iglesia. El primero de ellos, el título de beneficio, era "...el derecho perpetuo de percibir ciertas porciones de réditos eclesiásticos, por razón de un oficio espiritual" (Donoso Vivanco, 1849, p. 1243), y era el principal de los títulos atendibles para la ordenación. El título de patrimonio estaba constituido por "Los bienes propios del clérigo, poseídos por cualquier título legítimo" (Gómez Salazar, 1883, p. 147) y a él había dado origen el papa Alejandro III (1159-1181),

...cuando dispuso, que el obispo que hubiese ordenado á uno sin título, tenga obligación de mantenerlo hasta que obtuviese un beneficio eclesiástico con el que pueda atender á su honesta sustentación, nisi talis ordinatus de sua vel paterna haereditate, subsidium vitae possit habere" (Gómez Salazar, 1883, p. 147).

El título de pobreza se refería a los clérigos regulares, quienes podían ordenarse siempre que hubiesen profesado solemnemente en religión aprobada, toda vez que la religión o instituto religioso tenían la obligación de mantenerlo (Gómez Salazar, 1883, pp. 148-149). El título de servicio a la Iglesia fue introducido tardíamente, haciendo referencia a él un decreto Circa títulos sacrae ordinationis de 21 de junio de 1879, decreto que fue expresamente citado en el Concilio Plenario de América Latina y recogido en su apéndice XLIV -a este título había hecho referencia poco antes un decreto de la S.C. de Propaganda Fide, de 27 de abril de 1871 (Gómez Salazar, 1883, pp. 149-150)-, afirmando de él que "en nuestros países basta el título de administración o ministerio, o servicio de la Iglesia". (Iglesia Católica, Concilium Plenarium Americae Latinae, 1906, art. 582)

En lo que se refería al título de patrimonio, sugerían los metropolitanos españoles que debía suprimirse, puesto que, al menos en España, se encontraban muy pocos que podían constituir un verdadero patrimonio y, los que se constituían, casi todos no eran títulos reales como tal (Commissione Codice Diritto Canonico, s.f.l, 36). Es por lo que, dados la escasez de los beneficios y la pobreza de aquellos que se consagraban a los estudios eclesiásticos, consideraban "muy conveniente" que el título 
de servicio a la Iglesia fuere lo ordinario y suficiente (Commissione Codice Diritto Canonico, s.f.l, 35). Y coincidiendo con los prelados españoles, desde Brasil (Commissione Codice di Diritto Canonico, s.f.k, 2c) se solicitaba que el título del servicio de la diócesis fuere declarado legítimo en favor de las órdenes sagradas que se debían recibir.

El Codex (1917), en el canon 979, dispuso que el título canónico de ordenación era, para los clérigos seculares, el título de beneficio, y a falta de éste, el de patrimonio o de pensión, título que debía ser verdaderamente seguro para toda la vida del ordenado y verdaderamente suficiente para su congrua sustentación. De esta manera, el Codex desechó la petición española en orden a la supresión del título de patrimonio, si bien lo estableció de forma subsidiaria respecto del de beneficio, junto con el título de pensión; este último podía constituirse sobre frutos beneficiales, bienes eclesiásticos o bienes profanos, siendo fundamental que se garantizara su estabilidad (Alonso Lobo et al., 1963, p. 407). A falta de estos títulos "puede suplirse el título por el de servicio de la diócesis, y, en los lugares sujetos a la Sagrada Congregación de Propaganda Fide, por el título de misión" (Codex luris Canonici, 1917, can. 981, § 1); en virtud de este último título -que era calificado como un cuasicontrato- el ordenando se obligaba con juramento a permanecer perpetuamente al servicio de la diócesis o de la misión y el obispo adquiría la obligación de darle, una vez recibido el presbiterado, un oficio, beneficio o subsidio que fuere suficiente para su congrua sustentación. En otras palabras, la propuesta española fue acogida en cuanto que el título de servicio fue contemplado en el Codex (1917), pero no fue aceptado que "fuere lo ordinario y suficiente", pues sólo se aceptó a falta de los títulos anteriores. En cambio, la propuesta de los arzobispos de Brasil fue satisfecha, pues el título de servicio fue acogido en el Codex (1917), o sea se le consideró legítimo como ellos pedían, pero en la forma subsidiaria dicha.

Desde otra perspectiva, el arzobispo de Tarragona se hacía cargo de un problema que aquejaba a las dotes de los beneficios que se establecían en su tiempo, dote que consistía máximamente en títulos del Estado o en valores públicos, cuyas rentas estaban notablemente disminuidas (Commissione Codice di Diritto Canonico, s.f.i, 20). Sostenía el prelado que, cuando tal disminución producía un beneficio incongruo, parecía conveniente suspender su provisión, debiendo aplicarse las rentas a una masa de beneficios hasta que el beneficio llegare a ser congruo como antes. Lo mismo había que decir respecto de cualquiera de las otras fundaciones pías, a no ser que se previniere expresamente lo contrario en las cláusulas de la fundación. En lo que se refiere a estas últimas, el Codex dispuso que estaba reservada sólo a la Santa Sede la reducción de cargas que gravaban las piadosas fundaciones, a menos que se hubiese determinado otra cosa en la escritura de fundación (can. 1551 § 1); es por lo que, como la depreciación de la moneda era un hecho comprobado, la doctrina recomendaba como "muy conveniente", que al concertarse las fundaciones piadosas se autorizase por el fundador que el ordinario, cuando ello ocurriere, pudiere reducir 
Reformas al régimen patrimonial de la Iglesia Católica sugeridas desde España...

o suprimir algunas cargas, incluidas las misas (Alonso Morán y Cabreros de Anta, 1964, p. 186). Si dicha autorización no existía y, por haber disminuido las rentas o por otra causa, sin ninguna culpa de los administradores, resultaba imposible levantar las cargas, el ordinario, oyendo a quienes tuviesen interés en ello y cumpliendo la voluntad del fundador del modo más aproximado posible, podía disminuir las cargas, exceptuada la reducción de las misas, la que en este caso quedaba reservada a la Santa Sede (Codex luris Canonici, 1917, can. 1517, § 2). No se acogió lo que sugería el arzobispo tarraconense de aplicar los valores reducidos a una masa de beneficios, pero se le dio un amplio margen de acción, salvo las reducciones de misas que quedaron reservadas a la Santa Sede, debiendo el obispo hacer la respectiva petición.

\subsubsection{Otros medios para la sustentación de los sacerdotes}

El sustento de los sacerdotes era un tema no menor, de allí las propuestas anteriores; pero otro medio que podía ayudar a su manutención era sugerido desde España: sería muy conveniente, postulaban los metropolitanos españoles, que se otorgaren las máximas facilidades para la creación de alguna congregación de varones con votos simples, que se asignare al servicio de los sacerdotes (Commissione Codice Diritto Canonico, s.f.l, 32). Y serían estas entidades las que asegurarían el sustento de los sacerdotes (Commissione Codice Diritto Canonico, s.f.l, 36). Nada dijo el Codex (1917) sobre este tema.

Y los mismos metropolitanos postulaban que los clérigos fueren libres para trabajar en las artes y oficios mecánicos, siempre que el decoro sacerdotal y las sagradas obligaciones del ministerio no fueren menoscabadas $y$, en consecuencia, debía otorgárseles la facultad para poder vender, pero sin establecimiento comercial, objetos elaborados por mano propia $y$, al mismo tiempo, comprar las materias primas necesarias para desarrollar su propio trabajo (Commissione Codice Diritto Canonico, s.f.l, 43). Esta autorización era necesaria, porque, como lo recordaba el sínodo de Santiago de Chile de 1763 -por poner sólo un ejemplo- "No hay Prohibicion tan repetida en el Derecho Canònico, Breves Pontificios, Concilios Generales y particulares, como la de que los Clèrigos no tengan Trato y Negociación, habiéndose entendido hasta prohibirla por interpósita Persona" (Iglesia Católica. Diócesis de Santiago de Chile, 1858, p. 187), prohibición que, por cierto, era renovada en dicho sínodo. El Codex (1917) no innovó en esto, pues prohibió a los clérigos “...ejercer la negociación o el comercio por sí o por otros, sea para utilidad propia o ajena" (can. 142). En materia de negociación, sin embargo, la doctrina (Cabreros de Anta et al., 1963, pp. 425-430) postcodicial distinguió la negociación lucrativa -que existía cuando se compraban cosas con la intención de venderlas más caras, sin transformarlas previamente- de la negociación industrial -cuando se compraban las cosas para venderlas con lucro, pero después de haberlas transformado con trabajo humano propio o ajeno; en el caso de trabajo propio se hablaba de industrial en sentido amplio; en el caso de trabajo ajeno se hablaba de industrial estricta-. De ellas, estaba permitido a los clérigos la 
negociación industrial en sentido amplio, y se daba como ejemplo, precisamente, el señalado por los prelados españoles, esto es, los objetos producidos por el clérigo "con su digno y honroso trabajo", como escribir libros o confeccionar ropas de iglesia. La sugerencia hispana quedaba, así, acogida.

\subsubsection{Mutua renuncia de beneficios}

Una especie de renuncia de los beneficios era la permuta, definida como "La mutua renuncia de beneficios bajo la condición de que cada uno de los renunciantes obtenga el beneficio del otro" (Devotti, citado en Gómez Salazar, 1883, pp. 528-529). Era regla general que todos los beneficios podían permutarse, pero era necesario que mediare justa causa de necesidad o utilidad (Liber Extra 3, 19, 5), no bastando la utilidad y aún necesidad de los que trataban de permutar, porque se requería siempre y en todo caso que redundare, al menos indirectamente, en bien o provecho de la Iglesia. Era necesario, en todo caso, la intervención de la autoridad en esta materia, porque los beneficios eclesiásticos no podían obtenerse lícitamente sin la institución canónica (Liber Sextus 5, 12, reg. 1a), si bien, los clérigos que deseaban permutar podían desde luego tratar entre sí sobre este asunto, antes de acudir al superior (Gómez Salazar, 1883, p. 529). Desde Burgos (Commissione Codice di Diritto Canonico, s.f.a, 1/9), el arzobispo solicitaba que se no se asignare ninguna causa a la permutación de los beneficios, sino que se dejare a criterio de los ordinarios. El Codex trató de esta materia en el canon 1487, el que dispuso que para la validez de la permuta debía intervenir necesidad o utilidad de la Iglesia y otra causa justa, que debía apreciar el ordinario a quien correspondiere dar el consentimiento para que dicha permuta se verificare. El postulatum burgalés no tuvo exacto eco en el Código, pero se otorgaba al ordinario un adecuado margen de actuación al calificar la causa justa que justificaba la permuta.

\subsubsection{Contribuciones y tributos}

El prelado burgalés (Commissione Codice di Diritto Canonico, s.f.a, 3,12) sugería que se permitiere al obispo, para utilidad de la Iglesia, imponer contribuciones moderadas a los beneficios de rentas mayores cuando los confirieren por toda la vida del beneficiado; y que cada uno de los beneficiados, a prorrata de los frutos, pagare el subsidio del óbolo de San Pedro al romano pontífice (Commissione Codice di Diritto Canonico, s.f.a, 3,39). En términos similares se expresaba el arzobispo de Tarragona: según él, parecía necesario establecer que cualquier clérigo, cualquiera fuese su dignidad, tuviere que ceder una parte proporcional (por ejemplo, dos por ciento) de sus rentas, de manera que del total de lo recolectado por esta razón, fuere la mitad en subsidio del romano pontífice y de la Iglesia universal; y el resto, debía ser invertido por el ordinario para beneficio de la diócesis, por ejemplo, para que se construyere en la diócesis una casa piadosa donde los sacerdotes llegados a la vejez o por enfermedad, u obligados por pena de reclusión, pasaran una vida en paz y tranquila 
Reformas al régimen patrimonial de la Iglesia Católica sugeridas desde España...

(Commissione Codice di Diritto Canonico, s.f.i, 19). El Codex consideró la posibilidad de algunos tributos, pero lo hizo con moderación: además del tributo para el seminario (Codex luris Canonici, 1917, can. 1355-1356) o la pensión beneficial (Codex luris Canonici, 1917, can. 1429), autorizó al ordinario local, cuando lo reclamare una necesidad de la diócesis, a imponer un tributo extraordinario y moderado a todos los beneficiados tanto seculares como religiosos (Codex luris Canonici, 1917, can. 1505); no podía el ordinario imponer ningún otro tributo en favor de la diócesis o para el patrono de las iglesias, beneficios y demás institutos religiosos, como no fuere en el acto de la fundación o de la consagración, sin que pudiere imponer tributo alguno sobre los estipendios de las misas (Codex luris Canonici, 1917, can. 1506). A la luz de estos cánones, las propuestas de Burgos y Tarragona no fueron acogidas, de manera que cualquier tributo que los prelados quisieren imponer en sus iglesias particulares debían reconducirse a las posibilidades que les proporcionaba el Codex, la que les proporcionaba el medio preciso para subvenir a la necesidad que el prelado tarraconense sugería como ejemplo, esto es, la construcción en la diócesis de una casa piadosa donde los sacerdotes llegados a la vejez o por enfermedad, u obligados por pena de reclusión, pudieren pasar una vida en paz y tranquila.

Este último problema era abordado también por el conjunto de metropolitanos españoles para quienes, había que esforzarse para crear asociaciones de auxilio mutuo, por ejemplo, montes de piedad, en las diócesis en las que no hubiese establecido nada similar, para que hubiere una subsistencia segura para los clérigos enfermos y de edad avanzada (Commissione Codice Diritto Canonico, s.f.l, 34). El Código nada dijo de esto, sin perjuicio de que ello pudiera llevarse a la práctica por las diócesis que quisieren y pudieren realizarlo. Pero ofreció una vía de solución al conceder a los ordinarios del lugar la posibilidad de establecer pensiones beneficiales (Codex luris Canonici, 1917, can. 1429), si bien con la limitación de que no podían ser perpetuas por toda la vida del pensionado, sino sólo pensiones temporales, limitación que no valía para los beneficios parroquiales, pues un párroco podía renunciar a la parroquia -p. ej. por motivos de salud- con reserva de pensión sobre el beneficio parroquial en favor del párroco renunciante mientras éste viviere, con tal que no excediere de la tercera parte líquida de la renta fija del beneficio parroquial. Habría que esperar hasta el Concilio Vaticano II y al Código de Derecho Canónico de 1983 para que este problema fuere abordado orgánicamente.

\subsection{Cabildo eclesiástico}

\subsubsection{Intervención del cabildo eclesiástico en la administración de los bienes eclesiásticos}

“...el obispo y el cabildo constituyen un cuerpo para el gobierno y administración de las cosas eclesiásticas" (Gómez Salazar, 1883, p. 388), de allí que el obispo necesitase del consentimiento del cabildo catedral para enajenar cosas pertenecientes a iglesias 
inferiores a la catedral, cabildo con el que, antes de su consentimiento, el prelado debía tratar acerca de la necesidad o utilidad de la enajenación de bienes eclesiásticos, toda vez que, para la enajenación, debía tratarse de una necesidad urgente o de una utilidad evidente de la Iglesia. Con todo, no era la enajenación de bienes eclesiásticos la única ocasión en la que se requería la intervención capitular, pues los canonistas, analizando el capítulo De his, quae fiunt a prelato sine consensu capituli de las Decretales (Liber Extra 3, 10, 1-10), explicaban latamente los casos en que el derecho canónico exigía el consentimiento, casos que Donoso Vivanco $(1848$, p. 219) se encargaba de sintetizar. Sin embargo, las relaciones entre el obispo y el cabildo catedralicio no siempre fueron las mejores, con la consiguiente dificultad para la administración patrimonial, como que queda en evidencia en algunos de los postulata arribados a Roma tanto desde España como de Hispanoamérica.

En efecto, desde Chile se mostraba el problema, originado en el patronato, de que las autoridades republicanas presentaban los candidatos a las canonjías, lo que impedía que los obispos pudieren rechazar a los más indignos o a los poco idóneos para desempeñar esos cargos, de donde ocurría que "...por esta causa, la intervención del capítulo en la administración de la diócesis, no sólo en nada contribuye a una mayor tutela de la misma administración, sino que suele ser una molestia más perjudicial para la misma" (Commissione Codice di Diritto Canonico, s.f.h, 21); razón por la entendían que había que "disminuir aquella carga que grava a los obispos, de pedir a veces el consentimiento, a veces el consejo del capítulo, o de hacerlos partícipes en la administración de los negocios eclesiásticos" (Commissione Codice di Diritto Canonico, s.f.h, 21). En el mismo sentido, el arzobispo de Burgos pedía que se estableciere "que el obispo pueda él mismo disponer de todos los asuntos sin el consentimiento del capítulo" (Commissione Codice di Diritto Canonico, s.f.a, 3/4); y desde Brasil, siempre en el mismo sentido, los arzobispos de Rio de Janeiro y Sao Paulo preguntaban si debía darse prescripción "...a favor de los obispos contra la obligación de pedir el consentimiento del cabildo" (Commissione Codice di Diritto Canonico, s.f.k, 3c).

Más categóricos eran los obispos de la provincia eclesiástica de Buenos Aires, quienes pedían "que nunca esté el obispo obligado a pedir el consentimiento del cabildo eclesiástico, sino solamente el consejo y eso cuando lo creyere necesario" (Commissione Codice di Diritto Canonico, s.f.b., 96). Más aún, pedían derechamente

...que se supriman los cabildos eclesiásticos, capitula canonicorum, como ya se hace en las nuevas diócesis que se van erigiendo sin ellos y en vez de ellos que el obispo tenga su consejo de tres sacerdotes a los cuales consulte en los casos que crea de importancia o de dudosa solución. (Commissione Codice di Diritto Canonico, s.f.b., 96)

No se trataba de suprimir el órgano concejil, sino sustituirlo por otro más expedito, pero pedían los prelados argentinos que el obispo pudiere pedirles única- 
Reformas al régimen patrimonial de la Iglesia Católica sugeridas desde España...

mente consejo -no autorización-y ello sólo cuando el asunto se creyere de importancia o de dudosa solución. ¿Por qué esto? Porque los cabildos eclesiásticos eran "un real y verdadero tormentum episcoporum".

En el extremo norte de América Latina, en Venezuela, la realidad no era diferente. El arzobispo de Caracas, en cumplimiento de lo que había solicitado Roma, había hecho las consultas requeridas y enviado un informe a Roma, conocido por todos los que habían intervenido en él, entre los que, probablemente, que se encontraron los miembros del cabildo catedralicio. Pero, posteriormente, en forma privada envió un segundo informe reservado (Commissione Codice Diritto Canonico, s.f.ñ), conocido sólo por él, que de manera extensa abordada el problema de los cabildos eclesiásticos. No es del caso entrar en todas sus consideraciones, pero en el tema que me ocupa, consideraba el prelado que era "de importancia capital" obtener del papa una constitución apostólica que regulara las relaciones de los capítulos con los obispos, toda vez que, en Roma, más que en ninguna otra parte, se debía tener "una larga y penosa experiencia de las eternas cuestiones de los canónigos con los prelados" (Commissione Codice Diritto Canonico, s.f.ñ). El prelado reconocía que eran muchas las decisiones adoptadas por Roma sobre el tema, pero ellas andaban dispersas -uno de los grandes problemas del derecho común- lo que constituía

...una razón para que se haga un documento que las comprenda a todas, pues esta misma dispersión es causa de que sea casi imposible saberlo todo y no pocas veces se arman y se prolongan disputas sobre puntos ya decididos, pero cuya decisión no se conocía. (Commissione Codice Diritto Canonico, s.f.ñ)

El arzobispo caraqueño sugería algunos problemas que debían abordarse, distinguiendo la intervención del cabildo en la administración de los bienes de la catedral y en la de la diócesis. Respecto de los bienes catedralicios debía definirse lo que podía hacer el capítulo solo, y lo que no podía hacer sin el obispo; en sede vacante ¿el capítulo administraba solo las rentas de la catedral, o tenía en ello alguna injerencia el vicario capitular?; cuando el obispo estaba impedido por un impedimento indefinido y prolongado, como había sucedido en Caracas ¿cómo debía administrar el capítulo los bienes de la catedral y qué injerencia tenía en esa administración el vicario general? Además, debía también quedar resuelta como ley general, aunque ya lo estaba por decisiones de la Sagrada Congregación del Concilio, la independencia de los párrocos de las catedrales para administrar las rentas de la parroquia sin injerencia del capítulo.

En cuanto a la intervención del cabildo en la administración de la diócesis, preguntaba el arzobispo cuáles eran los casos en que se necesitaba el consentimiento del cabildo para que el acto del obispo fuere lícito y aún válido; según el prelado se conocía con claridad que se necesitaba para la enajenación de los bienes eclesiásticos y para la erección y división de beneficios; pero fuera de esos dos casos, "con- 
vendría que en todos los demás el capítulo no tuviera sino voto consultivo". El prelado, refiriéndose al artículo 231 del Concilio Plenario de América Latina de 1899 (1906) hacía presente que éste no hablaba "claramente sobre este asunto, sino que se refiere en general a casos que no determina, lo que es otra razón para consignar todo esto en el documento que me he permitido proponer".

El Codex no suprimió los cabildos de canónigos, sino que le dedicó un título completo, bajo el epígrafe "De los cabildos de canónigos" (Codex luris Canonici, 1917, can. 391-422), asignándole al cabildo catedral la tarea de ayudar al obispo "como un senado y consejo, y, mientras vaca la sede, le supla en el gobierno de la diócesis" (Codex luris Canonici, 1917, can. 391, § 1). En esta tarea, le asignó competencias en materia de administración de los bienes eclesiásticos, como señalo más adelante, por lo que las propuestas sugeridas en el sentido de suprimirlos o de disminuir sus atribuciones no tuvieron mayor eco en el Código con lo que el problema, al menos de momento, subsistió.

\subsubsection{Remuneración de los miembros del cabildo}

La remuneración que recibían los capitulares por el oficio desempeñado se hacía, en parte, sobre la base de su asistencia diaria al coro, lo que daba origen, en los cabildos españoles, a ciertos fraudes que los obispos españoles denunciaban, pero no describían. Es por lo que "para evitar completamente los fraudes", entendían que no era suficiente, a modo de incentivo, "separar la tercera parte de los frutos del beneficio y distribuirla entre los asistentes al coro", sino que era necesario establecer "repartos de todos los frutos de manera que únicamente los canónigos presentes en el coro puedan beneficiarse de ellos" (Commissione Codice Diritto Canonico, s.f.l, 10). Como el Tridentino había establecido el privilegio de tres meses de ausencia (Iglesia Católica, 1563, cap. 12), sugerían, además, los metropolitanos españoles que no debía reconocerse ninguna otra causa legítima que eximiera del coro,

...excepto por enfermedad del beneficiado, cuando ésta haya sido comprobada por el testimonio de dos canónigos quienes, como visitantes del enfermo y habiendo oído al médico, estén obligados en conciencia a decir si acaso el enfermo pueda o no ir a la iglesia. (Commissione Codice Diritto Canonico, s.f.l)

Desde Caracas la queja era similar, pues según su arzobispo,

...uno de los puntos que ofrece mayores dificultades y complicaciones, porque no siempre están compuestos los cabildos por sacerdotes de conciencia, lo que sucede en estos países con muchísima frecuencia, es la asistencia al coro y a los divinos oficios. Hay catedrales donde esta asistencia está en el más lamentable abandono, y hay que confesar que es uno de los casos más difíciles de remediar por la autoridad episcopal. (Commissione Codice Diritto Canonico, s.f.ñ) 
Reformas al régimen patrimonial de la Iglesia Católica sugeridas desde España...

Una medida que podía minimizar el problema era el pago que recibían los canónigos por asistencia a coro, de allí que considerara que

...en cuanto al pago de las asignaciones, a mí me pareció admirable lo que se hace en las basílicas de Roma, en las cuales no se paga al canónigo, sino su asistencia en cada día. Ojalá pudiera extenderse esto como ley para todos los capítulos". (Commissione Codice Diritto Canonico, s.f.ñ).

Quienes integraban el cabildo de canónigos tenían derecho a percibir prebendas y distribuciones. Las primeras consistían en algo fijo y se debía a los canónigos y beneficiados por razón de la residencia anual, sin relación con cada una de las veces que asistían al coro; las distribuciones, en cambio, variaban en conformidad con las horas canónicas a las que asistían de hecho. El Codex luris Canonic (1917), dispuso que "ganan las distribuciones los que son diligentes" (can. 395, § 3), para lo cual el mismo canon en el § 4 establecía que cada cabildo debía nombrar uno o varios censores o apuntadores que tomaren nota diariamente "de los que no asistan a los divinos oficios" (Codex luris Canonic, 1917, can. 395, § 4), pudiendo el obispo añadir otro apuntador. Las inquietudes planteadas en este sentido habían sido tenidas en cuenta por los codificadores.

\subsection{Enajenación y arriendo de bienes}

La mayor libertad solicitada por los obispos respecto del cabildo eclesiástica para la administración de bienes, tenían su complemento con otras propuestas que se hicieron a propósito de la enajenación y el arrendamiento, mayor libertad que no solo se pedía respecto de los cabildos, sino, incluso, de la misma autoridad apostólica. Así, desde España los metropolitanos consideraban que convenía que el ordinario, sin perjuicio de la necesidad de impetrar el beneplácito apostólico, pudiere autorizar la enajenación de los bienes de la Iglesia, al menos hasta diez mil libelos, de acuerdo al valor, en dicho momento, de la moneda y del desarrollo de la vida económica (Commissione Codice Diritto Canonico, s.f.l, 37). Desde Nicaragua se pedía que los obispos, fuera del consentimiento del capítulo, pudieren, por derecho propio, enajenar cualquiera de las cosas eclesiásticas si urgiere la necesidad o el peligro de usurpación -por parte del Estado- petición que respondía a las experiencias que había vivido la iglesia local en los años anteriores (Commissione Codice Diritto Canonico, s.f.m, 5). Y desde Lima (Commissione Codice di Diritto Canonico, s.f.e, 6) se hacía una propuesta genérica en el sentido de que se delegare permanentemente a los obispos para enajenar los bienes eclesiásticos, previas las condiciones exigidas por derecho.

Desde Michoacán, en México, también como respuesta a las dificultades que había experimentado la iglesia local en los años anteriores, se pedía reglas fáciles para la conservación de los bienes eclesiásticos, determinándose la manera con que debían ser administrados, y la forma a que debía sujetarse su enajenación, "porque las injustas leyes emanadas de la autoridad civil en esta materia, ya quitando a la 
iglesia la facultad de adquirir, ya creando incalificables trabas, hacen impracticables en gran parte las antiguas leyes del derecho canónico" (Commissione Codice di Diritto Canonico, s.f.f, 2). No se excluía expresamente la intervención del cabildo, pero bien puede entenderse implícitamente sugerida, pues, como lo expresaban otros episcopados, la intervención de dicho colegio era más una traba que una facilidad para la administración patrimonial.

Respecto de una mayor autonomía en relación con el beneplácito apostólico, los metropolitanos españoles avanzaban la propuesta de que era sumamente oportuno que en la enajenación que hicieren algunas iglesias, asociaciones o entidades eclesiásticas a otras también eclesiásticas, al interior de una misma diócesis, no se requiriere tal beneplácito apostólico (Commissione Codice Diritto Canonico, s.f.l, 38). Y el arzobispo de Burgos (Commissione Codice di Diritto Canonico, s.f.a, 3/13) proponía que, respecto de la enajenación, el permiso de la Santa Sede sólo fuere necesario cuando se tratare de cosas de gran valor, lo que era conveniente definir con anterioridad. De acuerdo con la disciplina vigente al tiempo de hacerse la consulta romana, la enajenación de las cosas eclesiásticas inmuebles o muebles preciosos se permitía si mediaba alguna causa justa, cumpliéndose, además, las solemnidades prescritas para la validez del acto, una de las cuales era el consentimiento del sumo pontífice, a menos que se tratare de cosas legadas o dadas a iglesia o monasterio que no podía adquirir bienes inmuebles según sus constituciones, o del caso de una grave y urgente necesidad que no daba tiempo para acudir a la Santa Sede, o si existía legítima costumbre contraria (Gómez Salazar, 1883, pp. 385-389). El Codex exigió para la enajenación de bienes eclesiásticos inmuebles o muebles que se podían conservar, licencia del superior legítimo sin la cual la enajenación era inválida (Codex luris Canonic, 1917, can. 1530, § 1, n 3); el superior legítimo quedaba definido por el valor del bien, siendo necesaria la licencia de la Santa Sede tratándose de bienes preciosos y de bienes cuyo valor excedía las 30.000 liras o francos (Codex luris Canonic, 1917, can. 1532, § 1). Esto es, la propuesta del prelado de Burgos en cuanto a los valores, quedó recogida en el Codex, el que precisó los valores para mayor claridad; pero nada dijo sobre las ventas al interior de la misma diócesis.

El mismo arzobispo burgalés (Commissione Codice di Diritto Canonico, s.f.a, 1, 13) hizo la única propuesta en relación con el contrato de arriendo, sugiriendo que se permitiere a los obispos arrendar los bienes eclesiásticos sin límite de tiempo. La disciplina vigente al tiempo de la consulta romana era que el arriendo no podía extenderse por más de un trienio (Clementinae, 3, 4,1; Extravagantes Communes, 3, 4 ún) si producía frutos anualmente; pero si los frutos se producían cada bienio o trienio, el arriendo podía extenderse “...por seis o nueve años (...) según la opinión común de los canonistas" (citado en Gómez Salazar, 1883, pp. 383-384); si excedía de estos términos, el arriendo requería el beneplácito apostólico. El Codex dispuso que el arriendo que excedía de 30.000 liras o francos y el que excedía de nueve años requería el beneplácito apostólico; si no pasaba de los nueve años, el superior legítimo para au- 
Reformas al régimen patrimonial de la Iglesia Católica sugeridas desde España...

torizarlo era el ordinario del lugar, con tal que obtuviere el consentimiento del cabildo de la catedral y del consejo de administración, además de aquellos a quienes interesare (Codex luris Canonic, 1917, can. 1541, § 2; 1532, § 3). Es decir, en esta materia la propuesta arribada desde Burgos no tuvo eco en el Codex.

\subsection{Religiosos}

Diversas propuestas episcopales abordaron aspectos patrimoniales de los religiosos, siendo algunas de sus propuestas comunes a los religiosos de uno y otro sexo, y otras propias de las religiosas.

\subsubsection{Propuestas comunes a religiosos y religiosas}

La esencia del estado religioso la constituyen los tres votos de obediencia, pobreza y castidad, siendo el fin principal perseguido por ellos la perfección de la caridad, pero los institutos religiosos se diferencian entre sí por el fin propio de cada uno de ellos, establecido por su fundador y por los medios y particulares ejercicios con que cada una tiende ora al fin general del estado religioso, ora al fin propio de cada uno de ellos. Una clasificación de los mismos permitía identificar, entre otras, las religiones mendicantes, que eran aquellas cuyos religiosos "...observan la pobreza en particular i en común, de manera que les es prohibido poseer bienes inmuebles; i solo se les permite vivir de limosnas i donaciones liberales de la caridad cristiana" (Donoso Vivanco, 1848, pp. 291-292). Es la razón por la que diversos privilegios que les fueron concedidos les permitían hacer cuestaciones y pedir limosnas con la sola autorización de sus superiores religiosos sin que el obispo tuviera intervención alguna en la autorización. Se trataba de privilegios necesarios, pero que podían dar lugar a abusos, los que, de hecho, se producían, lo que llevó al obispo chileno de la diócesis de San Carlos de Ancud, Ramón Ángel Jara, a pedir derechamente que se suprimiera a las órdenes mendicantes el privilegio de colectar limosnas sin permiso del obispo diocesano, puesto que "Son muchos y graves los abusos a que se presta esta excepción" (citado en Salinas Araneda, 2008, p. 189), postulatum que no es sino la queja frente a un problema real que debía enfrentar el obispo en su iglesia particular. El Codex, no se hizo eco de esta propuesta, si bien limitó en parte el privilegio, toda vez que dispuso que:

...los regulares que por su instituto se llaman mendicantes y lo son, pueden sin más licencia que la de sus superiores pedir limosna en la diócesis donde radica el convento; pero en otras diócesis necesitan además licencia, dada por escrito, del ordinario del lugar en donde desean recoger limosna. (Codex luris Canonic, 1917, can. 621, § 1)

Se recogía, así, en parte, la queja del prelado.

Un tema que interesaba al arzobispo de Quito, era el de la situación patrimonial de los religiosos que dejaban la vida religiosa, pero que, aun cuando habían 
abandonado el instituto religioso al que pertenecían, seguían siendo clérigos: proponía este prelado que los superiores regulares, cuanto pudiere ocurrir, gozaren de alguna jurisdicción sobre los religiosos que, sin dejar la vida consagrada, dejaban la vida religiosa, bien por dimisión o bien por dispensa, en tanto encontraren un obispo receptor, y los proveyeren de patrimonio eclesiástico (Commissione Codice di Diritto Canonico, s.f.g, 13b); y que del mejor modo que se pudiere, se proveyere en aquellas cosas que son para el decoro y sustento de los religiosos que salieren de los claustros, renunciados o dispensados, bien de votos simples, bien de votos solemnes (Commissione Codice di Diritto Canonico, s.f.g, 13c). Esta última preocupación era compartida por el arzobispo de Tarragona, quien pedía que se determinare a qué debía atenerse el ordinario de una orden o congregación para que, en lo tocante a los religiosos expulsados o secularizados, se evitare, en la medida de lo posible, aquella triste y como desesperada condición en la que no es raro se encuentren cuando están en tal estado (Commissione Codice di Diritto Canonico, s.f.i, 5). El Codex dispuso que quienes salieren de la religión o fueren despedidos de ella nada pueden reclamar por cualquier servicios que hubieran prestado (Codex luris Canonici, 1917, can. 643, § 1). Pero, si se trataba de una religiosa que había sido recibida sin dote y carecía de bienes con que atender sus necesidades, la religión debía darle "por caridad" lo necesario para que pudiere volver a su casa en forma segura y conveniente, y, "guardando la equidad natural", proveerla para que pudiere vivir decorosamente por algún tiempo, procediendo en eso de común acuerdo (Codex luris Canonici, 1917, can. 643, § 2). A los religiosos ordenados in sacris, en especial siendo ya sacerdotes, se acostumbró no conceder el indulto de secularización si antes no encontraban algún obispo que los recibiera en su diócesis (Cabreros de Anta et al., 1963, p. 931).

El arzobispo de Quito (Commissione Codice di Diritto Canonico, s.f.g, 8) abordaba otro tema, cual era el de la administración de los bienes de las congregaciones religiosas de votos simples y de misioneros cuando les eran donados sin que el objeto de la misma donación se hubiese indicado con palabras claras: en estos casos, sugería que la administración de esos bienes fuere hecha por el obispo y el moderador de dichas congregaciones. El Código nada dijo sobre este particular.

Finalmente, en lo que se refiere al testamento hecho por religiosas, los metropolitanos españoles (Commissione Codice Diritto Canonico, s.f.l, 40) pedían que se extendiera a la iglesia universal lo que una instrucción de la Sagrada Penitenciaría de 18 de abril de 1867 había dispuesto a favor de Italia en el sentido que era suficiente la autorización del ordinario para que una religiosa pudiese redactar testamento, y un permiso del superior general si se trataba de un religioso; incluso más, entendían los prelados hispanos que sería sumamente conveniente que fuere declarado que las autorizaciones antes mencionadas también fueren suficientes para cualquier acto de dominio o de propiedad (Cardenal A. M. Panebianco, 1867). El Codex (1917, can. 569, $\S 3)$, dispuso de manera general que el novicio de congregación religiosa Congregación religiosa o simplemente congregación, es la religión donde sólo se 
Reformas al régimen patrimonial de la Iglesia Católica sugeridas desde España...

emiten votos simples, ya sean perpetuos, ya temporales (Codex luris Canonici, 1917, can. $488, n^{\circ} 2$ ). Voto simple es la promesa espontánea y deliberada hecha a Dios de entregarse a su servicio por medio de los tres consejos evangélicos de obediencia, pobreza y castidad, sin que medie aceptación para siempre por la Iglesia-, antes de la profesión de votos temporales, debía hacer testamento, disponiendo libremente de sus bienes presentes o de los que talvez pudieren después venirle; como se afirmaba la libertad de testar, nada podía decir de posibles autorizaciones, pero los superiores y superioras debían velar para que se cumpliera dicha obligación y la ejercieran con plena libertad. A los novicios de órdenes religiosas -Orden, es la religión en la que se emiten votos solemnes (Codex luris Canonici, 1917, can. 488, n² 2). Voto solemne es la promesa espontánea y deliberada hecha a Dios de entregarse a su servicio por medio de los tres consejos evangélicos de obediencia, pobreza y castidad, aprobada y aceptada por la Iglesia-, el Codex ni se los mandó ni se los prohibió, pero si lo hacían, quedaba anulado por la renuncia de los bienes que tenían que hacer, a tenor del canon 581, antes de la profesión solemne.

\subsubsection{Propuestas comunes a religiosos y religiosas}

Las postulantes a la vida religiosa debían llevar una dote, según lo determinasen las constituciones o la costumbre legítima, la que se daba como una ayuda para atender al sustento de la religiosa, dote que, al tiempo de la consulta al episcopado, se exigía que se entregara en dinero contante. Ocurría, sin embargo, que esto daba lugar a cuestiones enojosas que, con menoscabo de la paz y del decoro de las comunidades religiosas, podían llevarse a los tribunales civiles. Esto hizo que el arzobispo de Santiago de Chile, probablemente a partir de experiencias concretas, sugiriese que parecía oportuno establecer lo que él proponía que debía hacerse con la dote de las religiosas: la dote debía recibirse bajo contrato, en el que debía estipularse: $1^{\circ}$ que, una vez verificada la profesión perpetua, la comunidad adquiere en pleno e irrevocable dominio la cantidad entregada en dote; $2^{\circ}$ que la comunidad se obligaba a la manutención de la profesa conforme a la disciplina religiosa; y $3^{\circ}$ que la comunidad quedaba obligada a la restitución de una cantidad igual a la de la dote, sin intereses, sólo en los casos siguientes: i) de no verificarse la profesión; ii) de declararse nula por la autoridad de la Iglesia; iii) de ser la profesa expulsada o dimitida; iv) de haberse secularizado por indulto apostólico o por dispensa de sus votos; y v) de haber pasado a otro instituto con la debida licencia eclesiástica. El contrato de dote se extendería por escritura pública ante notario civil; la cual sería firmada por la superiora de la comunidad o la religiosa que, por ausencia o impedimento de ella, hiciere sus veces, y por la novicia o persona que diere la dote $y$, si no fuere mayor de edad y no tuviere la libre administración de sus bienes, por su representante legal (Commissione Codice di Diritto Canonico, s.f.h, 38). Esta propuesta recogía textualmente una norma propia vigente en el arzobispado de Santiago, que había sido establecida en el sínodo de Santiago de 1895 (Iglesia Católica. Diócesis de Santiago de Chile, 1895, art. 957). 
El Codex distinguió entre monasterios de monjas y religiones de votos simples, estableciendo para los primeros que la postulante debía llevar la dote que las constituciones o la costumbre legítima determinaba (Codex luris Canonici, 1917, can. $547, \S 1)$, de manera que antes de tomar hábito debía entregarse la dote al monasterio, o por lo menos debía asegurarse su entrega en forma válida ante el derecho civil (Codex luris Canonici, 1917, can. 547, § 2); en lo que tocante las religiones de votos simples debían atenerse a lo que dispusiesen las costumbres (Codex luris Canonici, 191 , can. 547, § 3). La dote pasaba irrevocablemente a ser propiedad del monasterio o de la religión al morir la religiosa, aun cuando ella hubiese emitido sólo votos temporales (Codex luris Canonici, 1917, can. 548). Una vez que la religiosa hacía la primera profesión, la superiora con su consejo y el consentimiento del ordinario local -y del superior regular, si la casa dependía de éste- debía colocar la dote en valores seguros, lícitos y fructíferos, "quedando prohibido en absoluto gastarla de cualquier forma antes que la religiosa muera, ni aun para edificar casa o pagar deudas" (Codex luris Canonici, 1917, can. 549). A la religiosa profesa, tanto de votos solemnes como de votos simples, que saliere del instituto, por cualquier motivo que lo hiciere, se debía restituir la dote íntegra sin los réditos ya vencidos (Codex luris Canonici, 1917, can. 551, § 1); si una religiosa profesa pasaba con indulto apostólico a otra religión, durante el noviciado, los frutos de la dote debían entregarse a la nueva religión, y la dote completa después que profesare; si pasaba a otro monasterio de la misma orden, a él debía entregarse la dote desde el mismo día del tránsito (Codex luris Canonici, 1917, can. 551, § 2). Como puede advertirse, la propuesta chilena no estuvo muy alejada de la regulación que el Código dio a esta materia.

\subsection{Sacramentos y sacramentales}

Otro conjunto de propuestas arribadas desde España y América Latina se refirieron a la dimensión patrimonial de la administración de algunos sacramentos y sacramentales. Donoso Vivanco (1848) explica que:

Derechos útiles de los párrocos, son las oblaciones o prestaciones, que, con arreglo a leyes y costumbres laudables, tienen derecho de exijir, en el ejercicio de ciertos actos del ministerio, para subvenir a su congrua sustentación, i a las expensas que demandaba el cumplido desempeño de las funciones de su cargo. (p. 254)

El 10 de junio de 1896 había declarado la S. C. del Concilio que no debía dejarse a disposición de cada obispo el señalar las tasas que hubieren de regir en las respectivas diócesis, sino que eso debía tratarse en los concilios provinciales o en las asambleas de obispos, bajo la condición de fijar, en cuanto fuera posible, una tasa uniforme para cada provincia eclesiástica. No obstante esta declaración hecha poco antes de la consulta romana, desde Argentina se solicitó que el arancel eclesiástico fuere para cada diócesis y no para toda la provincia eclesiástica, pues "entre nosotros" este era imposible por la diversa condición de los católicos en las distintas dió- 
Reformas al régimen patrimonial de la Iglesia Católica sugeridas desde España...

cesis de la provincia eclesiástica (Commissione Codice di Diritto Canonico, s.f.b, 9). Esta propuesta no tuvo eco en el Código, el que, recogiendo la declaración de 1896 aparece entre las fuentes del Codex luris Canonici (1917, can. 1507), con anotación de las fuentes de cada canon)-, dispuso que pertenecía al concilio provincial o a la asamblea de los obispos de la provincia el fijar las tasas que había que pagar en toda la provincia eclesiástica por los varios actos de jurisdicción voluntaria o por ejecutar los rescriptos de la Sede Apostólica o con ocasión de administrar los sacramentos o sacramentales, pero dichas tasas carecían de todo valor antes de ser aprobadas por la Sede Apostólica (Codex luris Canonici, 1917, can. 1507, § 1). El Codex, en esto, fue más exigente que la declaración de 1896, porque ésta hablaba de fijar una tasa uniforme en cuanto fuera posible.

En relación con las exequias, desde Santiago de Chile parecía que había que declarar que no se tuvieren exequias, o fueren solventados los gastos de funerales solemnes, sino en la propia iglesia parroquial, o, si en otra, en la que antes hubiere impetrado la licencia del párroco o del ordinario (Commissione Codice di Diritto Canonico, s.f.h, 43). El Codex expresamente estableció que, por derecho ordinario, la iglesia donde debía ser trasladado el cadáver para el funeral era la parroquia propia del difunto, a no ser que éste hubiese legítimamente elegido otra iglesia para el funeral; si el difunto tenía varias parroquias propias, la iglesia del funeral era la de la parroquia en cuyo territorio había fallecido (Codex luris Canonici, 1917, can. 1216).

Podía suceder que a un fiel no se le hiciese funeral en su propia iglesia parroquial, en cuyo caso debía darse al párroco propio del difunto la porción parroquial, esto es, una participación en los emolumentos del funeral, conocida como cuarta funeral, denominación que prevaleció sobre otras -porción canónica, justicia- porque la práctica más frecuente señalaba la cuarta parte de tales emolumentos. Desde Burgos (Commissione Codice di Diritto Canonico, s.f.a, 3/28) se pidió que siempre se reservase la cuarta funeral, aunque obstare costumbre o privilegio. La propuesta encontró eco en el Codex, pues en el canon 1236 dispuso que, dejando a salvo el derecho particular, siempre que a un fiel no se le hacían funerales en su propia iglesia parroquial, se debía dar la porción parroquial al párroco proprio del difunto, exceptuado el caso en que el cadáver no pudiere ser trasladado cómodamente a la iglesia parroquial propia (Codex luris Canonici, 1917, can. 1236, § 1); si el difunto tenía varias parroquias propias a las que podía trasladarse cómodamente el cadáver, y los funerales se celebraban en otro lugar, la porción parroquial -cuarta funeral- debía distribuirse entre todos los párrocos propios (Codex luris Canonici, 1917, can. 1236, § 2). Aunque la denominación cuarta funeral siguió siendo usada por algunos canonistas, el monto de la misma debía fijarse en el arancel diocesano, y si la iglesia parroquial y la funerante pertenecían a diócesis distintas, debía atenderse al arancel de la iglesia funerante (Codex luris Canonici, 1917, can. 1237, § 3). 
Una última propuesta acerca de las exequias llegó a Roma también desde Santiago de Chile, según la cual había que prohibir que se celebraren ritos exequiales en el cementerio a menos que previamente se hubieren pagado las deudas por los derechos parroquiales (Commissione Codice di Diritto Canonico, s.f.h, 43). El Codex nada dijo sobre el particular, pero en una norma expresa dispuso que a los pobres se les debía funerar y enterrar completamente gratis y de una manera decorosa, con las exequias prescritas conforme a los libros litúrgicos y a los estatutos diocesanos (Codex luris Canonici, 1917, can. 1235, § 2).

Finalmente, desde México, el arzobispo de Antequera, invocando el Tercer Concilio Mexicano (1585), pedía que se prohibiere que las contribuciones de las misas fueren enviadas a otra parte por las congregaciones más recientes sin la venia del obispo (Commissione Codice di Diritto Canonico, s.f.j, 8). El III Concilio Provincial Mexicano (Martínez Ferrer, 2009) había dispuesto a todas las personas a cuyo cargo estaba el hacer decir misas, como curas, capellanes, albaceas o ejecutores de testamentos, mayordomos de cofradías o congregaciones "que no embíen missas e limosna dellas para que se digan fuera de la dióçesi, donde residen, y mucho menos a España, so pena de excomunión mayor "latae sententiae»" (citado en Martínez Ferrer, 2009), a menos que para algún caso particular y muy urgente el prelado diere licencia, "sobre lo cual se le encarga la consçiençia" (citado en Martínez Ferrer, 2009). Esta norma amerita una explicación: la costumbre de ofrecer a un sacerdote una suma de dinero para que aplicara la misa por una intención particular parece haberse introducido en la Iglesia a principios del siglo VIII, y fue llamada ordinariamente estipendio. Esta suma de dinero, según explicaba Donoso Vivanco (1849), no se daba ni recibía “... como precio del divino sacrificio, que eso sería incurrir en gravísimo delito de simonía, sino como una erogación debida al sacerdote que, ocupado en el servicio del altar, tiene derecho para percibir, del altar, su congrua sustentación..." (pp. 86-87). El monto de este estipendio era fijado por el obispo. Podía ocurrir, empero, que quien recibía stips missae no estuviera en condiciones de poder celebrar por sí mismo la o las misas encomendadas, de donde se autorizaba para que transmitiera los estipendios y la obligación de celebrar la o las misas encargadas a otros sacerdotes para que estos pudieren celebrarlas. La norma conciliar mexicana aludida por el prelado de Antequera no impedía esta práctica, sólo le imponía un límite: los estipendios podían ir de un sacerdote a otro, pero sólo al interior del obispado donde residía el sacerdote a quien se entregaba el estipendio, a menos que se contara con la licencia del prelado para que pudiera enviarse fuera.

El Codex dispuso que a nadie le era lícito aceptar, para celebrarlas por sí mismo, tantas misas que no pueda cumplirlas en el plazo de un año (Codex luris Canonici, 1917, can. 835); sin perjuicio de ello, quien tuviere misas que debían ser celebradas por otros, debía distribuirlas cuanto antes (Codex luris Canonici, 1917, can. 837) y quien tenía algún número de misas de las que podía disponer, podía dárselas a sacerdotes que fueren de su agrado, si con toda certeza le constaba que no tenían ta- 
Reformas al régimen patrimonial de la Iglesia Católica sugeridas desde España...

cha o que estaban recomendados por testimonio de su ordinario propio (Codex luris Canonici, 1917, can. 838); uno y otro debían traspasar, sin merma, los estipendios recibidos, a menos que el oferente les hubiese permitido expresamente retener una parte (Codex luris Canonici, 1917, can. 840, § 1). En todo caso, los que encargaban a otros la celebración de misas recibidas de los fieles o de cualquier modo confiadas a su fidelidad, permanecían obligados, en tanto no se les participara que aquéllos habían aceptado la obligación y habían recibido el estipendio (Codex luris Canonici, 1917, can. 839).

Nada dijo el Codex acerca de lo postulado desde Antequera. Existía, sin embargo, lugares en los que el derecho particular, como había sucedido con el III Concilio Mexicano, establecía la prohibición de enviar misas fuera de las diócesis, lo que motivó una consulta a la Sagrada Congregación del Concilio en orden a si podía mantenerse en vigor la ley diocesana. La respuesta de la Congregación romana, hecha el 19 de febrero de 1921, fue en estos términos: "Subsiste en cuanto a las misas fundadas, cuasimanuales y manuales, dadas en consideración a una causa pía; en las demás, guárdese el canon 838" (Benedicto XV, 1921, p. 230), dicho canon señala que "Los que tienen algún número de Misas de las que pueden disponer libremente, pueden dárselas a sacerdotes que sean de su agrado, si con toda certeza les consta que no tienen tacha o que están recomendados por testimonio de su Ordinario propio" (Codex luris Canonici,1917, can. 838). Es decir, salvada la excepción, se entendió que las leyes particulares que habían establecido la prohibición de enviar misas fuera de la diócesis habían quedado derogadas (Alonso Lobo, Miguélez Domínguez y Alonso Morán, 1963, pp. 242-243). De esta manera la propuesta de los prelados del arzobispado mexicano de Antequera no sólo no fue acogida, sino que se entendió que estaba derechamente derogada.

A modo de definición de lo antes expuesto, señalar que Misas fundadas son aquellas cuyos estipendios proceden de los réditos de una pía fundación estrictamente tal. Cuando se trataba de un capital dejado en favor de cualquier obra pía o benéfica no erigida en persona moral eclesiástica las misas y los estipendios se entendían manuales. Misas cuasimanuales o a manera de manuales eran las que estaban fundadas en una iglesia o iban anejas a un beneficio, pero que no podían celebrarse en la iglesia asignada ni por el beneficiado, en cuyo caso debían celebrarse en otros lugares o entregarse a otro sacerdote. Misas manuales eran las encargadas por los fieles dando el estipendio libremente, o por encargo del testador; pueden encomendarse a cualquier sacerdote para que las diga donde mejor le parezca. (Alonso Lobo et al., 1963, pp. 235-236).

\subsection{Testamentos, contratos, prescripción, usura}

Un par de propuestas se refirieron a los testamentos. Los metropolitanos españoles pedían que, en lo que respecta a los testamentos -y contratos- debía exigirse que cualquier cambio debía hacerse ante la vista de todos (Commissione Codice Diritto Canonico, s.f.l, 39). Por su 
parte, el arzobispo de Burgos pedía que se prohibiere a los que tenían el cuidado de las almas, testar acerca de cualquier documento y utensilio sagrado y también acerca del peculio adquirido no de donación para que, como expolio, pertenecieran a la Iglesia en la cual tenían beneficio (Commissione Codice di Diritto Canonico, s.f.a, 3/26). Ambas propuestas tuvieron eco en el Codex, si bien no en los mismos términos en que habían sido formuladas. Así, en lo que se refiere al cambio de testamento, esa posibilidad se reguló con ocasión del testamento de los profesos de votos simples en las congregaciones religiosas, a quienes no les estaba permitido cambiar el testamento hecho sin licencia de la Santa Sede; nada se decía que el cambio se hiciera ante la vista de todos, pero se requería licencia de la Santa Sede y, si el caso urgía y no había tiempo de acudir a ella, el cambio no podía hacerse sin licencia del superior mayor, o del superior local, si ni tiempo había para acudir al mayor (Codex luris Canonici, 1917, can. 583, n²). En cuanto a la propuesta burgalesa, también tuvo eco en el Codex, el que en los cánones 1298-1300 se refirió a los utensilios sagrados y demás objetos destinados en forma estable al culto divino pertenecientes a los cardenales difuntos (Codex luris Canonici, 1917, can. 1298), obispos residenciales (Codex luris Canonici, 1917, can. 1299) y clérigo que hubiera obtenido en alguna iglesia un beneficio secular o religioso (Codex luris Canonici, 1917, can. 1300), los que quedaban para las respectivas iglesias, lo que todos ellos debían procurar que se hiciese efectivo en el fuero civil mediante la obligación de hacer testamento $\mathrm{u}$ otro instrumento redactado en forma que fuere válido ante el derecho civil (Codex luris Canonici, 1917, can. 1301).

En lo referido a la prescripción, desde Santiago de Chile se pedía que en algún título del nuevo código estuviere la prescripción en las cosas, las acciones y las penas dentro del dominio del derecho canónico (Commissione Codice di Diritto Canonico, s.f.h, 47). En lo que a las cosas se refiere, que es lo que ahora me interesa, el Codex dedicó cinco cánones a tratar la materia (Codex luris Canonici, 1917, can. 1508-1512). En el primero de ellos, establecía la regla general de aceptar para los bienes eclesiásticos la prescripción como un modo de adquirir algún derecho o de librarse de alguna carga, según estaba en la legislación civil de la respectiva nación, pero, en los cánones siguientes establecía algunas peculiaridades propias, en concreto, definir qué bienes no estaban sujetos a prescripción (Codex luris Canonici, 1917, can. 1509), la prescripción de cosas que se hallaban bajo el dominio de los particulares (Codex luris Canonici, 1917, can. $1510, \S 1$ ) o de personas morales (Codex luris Canonici, 1917, can. 1510, § 2), el plazo de prescripción -cien años para los bienes inmuebles, los muebles preciosos, los derechos y acciones, tanto personales como reales, que pertenecían a la Sede Apostólica (Codex luris Canonici, 1917, can. 1511, § 1) y 30 años para los que pertenecían a otra persona moral eclesiástica (Codex luris Canonici, 1917, can. 1511, § 2)- y la regla general de que ninguna prescripción valía si no había buena fe, no sólo al comienzo de la posesión, sino todo el tiempo de la misma que se requiere para la prescripción (Codex luris Canonici, 1917, can. 1512). De esta manera, el postulatum chileno tuvo cumplida satisfacción en el Código finalmente aprobado.

Como acabo de señalar, los metropolitanos españoles habían sugerido que en materia de testamentos y contratos debía exigirse que cualquier cambio debía hacerse ante la vista de todos. Era, sin embargo, sólo una referencia genérica a los con- 
Reformas al régimen patrimonial de la Iglesia Católica sugeridas desde España...

tratos. Más específicos eran estos prelados cuando escribían en sus postulata que "convendría muchísimo" que la doctrina acerca del mutuo y de los intereses fuere expuesta más clara y precisamente (Commissione Codice Diritto Canonico, s.f.l, 39). Y a propósito del mutuo, complementaba esta petición la del arzobispo de Guatemala (Commissione Codice di Diritto Canonico, s.f.d, 4), quien abordaba expresamente el tema de la usura, lo que hacía formulando una seria de preguntas que él proponía que debían ser consideradas: i) ¿acaso de Lucas 6: 35 que señala: “Amad, pues, a vuestros enemigos, y haced bien, y prestad, no esperando de ello nada; y será vuestro galardón grande, y seréis hijos del Altísimo; porque él es benigno para con los ingratos y malos" (Lucas 6:35 Reina Valera 1960) y de otros lugares de la Sagrada Escritura acerca de esta materia no se había de entender que todo interés por préstamo de dinero estaba prohibido por derecho divino? Por otra parte: ¿Acaso la usura no estaba condenada en las páginas sagradas como una misma entidad moral que la estipulación que ahora llamamos mutuo con interés? ii) ¿acaso el principio de derecho natural prohíbe a uno aceptar algo de dinero en dominio sobre capital puesto a ganancias con mutuario que pague libremente y por propia voluntad, excluido todo dolo o coacción? iii) ¿si la actual usura -largamente distante de la judaica- que estaba excluida por derecho natural y divino, podría la Iglesia consentir, antes bien aprobar, el permiso hecho por los gobiernos católicos de recibir algo sobre capital puesto a ganancias? iv) el dominio de los gobiernos, declarado eminente -lo que se alegaba en Guatemala- ¿era acaso verdadero dominio, antes bien verdadero derecho privado de dominio eficaz en sus cosas, o más bien -como parecía manifiesto- solo una suprema administración, que permitía el despojo de las cosas privadas o como se decía entonces una expropiación por utilidad pública, sin embargo, cuando el dueño es compensado exactamente con el justo precio? v) ¿acaso hubiese podido la Iglesia aprobar la aceptación de intereses con un título de la ley civil no concurrente? vi) bien examinado todo esto ¿no sería conveniente establecer en la ley canónica una noción más legítima del delito de usura, así, por ejemplo, definirlo: "delito por el cual alguien que abusa de la ignorancia de otro o de su necesidad le exige mayores intereses de dinero que la ley o la costumbre permite?" (Commissione Codice di Diritto Canonico, s.f.d, 4)

El Codex (1917) no definió la usura, pero se refirió a ellas en dos cánones: en el primero - can. 1543- dispuso que, si se entregaba a alguien una cosa fungible, de tal suerte que pasase a ser suya y después tuviere que devolver otro tanto del mismo género, no se podía recibir ninguna ganancia por razón del mismo contrato; pero al prestar una cosa fungible, no era de suyo ilícito estipular el interés legal, siempre que no constase que era excesivo, y aun uno más alto, si había título justo y proporcionado que lo cohonestase. En el segundo -can. 2354- dispuso que el seglar que hubiese sido legítimamente condenado por el delito de usura -entre otros delitos que mencionaba el canon- se le tenía que considerar excluido por el derecho mismo de los actos legítimos eclesiásticos y de cualquier cargo que pudiese tener en la Iglesia, 
quedando en pie la obligación de reparar los daños (Codex luris Canonici, 1917, can. $2354, \S 1)$; si fuese clérigo, debía ser castigado por el tribunal eclesiástico, según la gravedad de la culpa, con penitencias, censuras, privación de oficio y beneficio y de dignidad, y, si el caso la pedía, hasta con deposición (Codex luris Canonici, 1917, can. $2354, \S 2)$.

\subsection{Personas jurídicas}

La noción de persona jurídica se incorporó al derecho canónico gracias al trabajo de los canonistas del derecho común (Salinas Araneda, 2009) ${ }^{1}$, de donde pasó al derecho de los Estados, convirtiéndose hoy en patrimonio jurídico común. El Código Civil de la República de Chile (1855), a diferencia de lo que había ocurrido con el Código Civil de los Franceses (1804), conocido también como Código Napoleón, dedicó un título completo del Libro primero -el título XXXIII- a las personas jurídicas, normas que sirvieron a los prelados chilenos para proponer que el código canónico que se preparaba contuviere normas sobre este tipo de personas, algunas de las cuales abordaban aspectos patrimoniales. Decía el arzobispo de Santiago que sería completamente conveniente que el código canónico sancionare los principios y las reglas que atañían a las personas jurídicas eclesiásticas, en que concurrieren, en lo que ahora me interesa, estas materias: determinar cuáles serían los derechos de estas personas, qué facultades, qué obligaciones serían propios y peculiares de las personas que las representaban, y en general el régimen de éstas; además, debía indicarse el modo por el cual estas personas se extinguirían y lo que debía hacerse cuando sus constituciones nada hubiesen dispuesto acerca de los bienes de las extintas (Commissione Codice di Diritto Canonico, s.f.h, 44). Para ayudar a los codificadores canónicos, no consideraron superfluo hacer uso del Código Civil (1855) chileno en sus postulata, del que se transcribían algunos artículos, traducidos al latín, entre los que se encontraban los artículos 549 y $561^{2}$, que trataban materias de carácter patrimonial referentes a estas personas.

[inc. $1^{\circ}$ ] Bonorum omnium, quae pertinent alicui societati, neque tota neque pars aliqua pertinet cuipiam e personis, societatem constituentibus; atque eodem modo sodalitii debita nemini jus tribuunt ipsa repetendi seu in partem seu in totum a quopiam sodalitium constituente, aut in judicis postulandi istius bona. Tantum repeti possunt illa bona, quae sodalitis pertinent. [inc. $2^{\circ}$ ] Attamen sodalitii socii possunt, cum id expresse dicant, sese obligare suarum bonorum sponsione, simul ac sodalitas sese communium bonorum sponsione obligat: et tunc unusquisque a sociis in solidum tenetur ad debita solvenda, si solidarietas expressis verbis statuta fuerit. [inc. $3^{\circ}$ ] Haec tamen sponsionis obligatio ad haeredes haud transit,

\footnotetext{
1 Y la bibliografía allí citada.

${ }^{2}$ Se divide en dos incisos este artículo que en el Código Civil es un inciso único.
} 
Reformas al régimen patrimonial de la Iglesia Católica sugeridas desde España...

nisi cum sodalitatis socii eos expresse obligaverint. [inc. $4^{\circ}$ ] Cum aliqua sodalitas legalem existentiam non habuerit ad mentem articuli 546, ejus collective actos omnes et unumquemque e sociis in solidum obligant. (citado en Commissione Codice di Diritto Canonico, s.f.h).

[inc. $1^{\circ}$ ] Soluta societate, ejusdem bona ea disponentur forma quae ad hoc praescripta fuerit in ipsius societatis constitutionibus, ac, cum hic casus haud praevisus fuerit, ipsorum bonorum Respublica potietur, hac tamen obligatione, ut eis utatur ad fines haud dissimiles ab illis, ad quos constituta fuerint. [inc. $2^{\circ}$ ] Legislatorum Collegio hos fines indicare proprium erit.(citado en Commissione Codice di Diritto Canonico, s.f.h).

El Codex dedicó cinco cánones a las personas morales -Codex luris Canonici, 1917, cann. 99-103- ninguno de los cuales, sin embargo, abordó materias patrimoniales. Pero en el canon 1501 dispuso que, al extinguirse una persona moral eclesiástica, sus bienes pasaban inmediatamente a ser de la persona moral eclesiástica inmediatamente superior, dejando siempre a salvo las voluntades de los fundadores o donantes, los derechos legítimamente adquiridos y las leyes particulares por las que se regía la persona moral extinguida.

\subsection{Abusos de los gobiernos seculares sobre los bienes eclesiásticos}

Uno de los problemas que debió enfrentar la Iglesia durante la segunda mitad del siglo XIX, tanto en España como en la América hispana, fue la decisión de algunos gobiernos, especialmente anticlericales, de intervenir en los bienes eclesiásticos, apropiándose de parte no menor de ellos, lo que, en general, puede englobarse en las llamadas políticas desamortizadoras, esto es, arrancar de las manos muertas los bienes que se encontraban fuera del comercio. Se trataba, empero, de bienes eclesiásticos cuya condición jurídico-canónica era menester aclarar, además que surgía la necesidad de los gobiernos estatales de reparar los daños patrimoniales causados a la Iglesia por estas políticas, lo que se facilitaba por la alternancia en el poder, de gobiernos liberales anticlericales y conservadores. Los acuerdos sobre estas materias, sin embargo, y las conversaciones con los gobiernos, eran conducidas siempre desde Roma y ello solía ocurrir con la firma de concordatos, en los cuales esta materia era expresamente abordada. España no se vio libre de esto, y es por lo que desde Burgos, el arzobispo pedía que todos los obispos pudieren conceder la facultad de enmendar y de retener, bajo las condiciones definidas por la Santa Sede, los bienes eclesiásticos tomados por los gobiernos (Commissione Codice di Diritto Canonico, s.f.a, 2/17). Nada dijo el Codex sobre esta materia. 


\section{Consideraciones finales}

Puesto que el tema patrimonial no era de menor importancia en la Iglesia, las propuestas que fueron enviadas desde España y América Latina en respuesta a la petición hecha por la Santa Sede para que se hicieran presente las reformas que se consideraban convenientes introducir al derecho canónico vigente al momento de confeccionar un Codex luris Canonici (1917), incluyeron sugerencias sobre aspectos del derecho patrimonial de la Iglesia: provinieron ellas del conjunto de los metropolitanos españoles y de los arzobispos de Burgos y Tarragona, ambos prelados españoles; es decir, todos los postulata hechos desde España abordaron la materia patrimonial. Desde América Latina lo hicieron los arzobispos de Santiago de Chile, Buenos Aires, los dos arzobispos de Brasil, Quito, Caracas, Lima, Guatemala, los arzobispos de Michoacán, Antequera y Durango en México, y los obispos de San Carlos de Ancud en Chile y de Nicaragua. La preocupación sobre esta materia era evidente.

Por lo general las propuestas pretenden dar mayor libertad al obispo al tiempo de decidir sobre algunas de las materias patrimoniales: lo sugieren en diversas ocasiones los distintos episcopados a propósito de materias diferentes, pero coincidentes en la misma dirección, de manera de eliminar o disminuir la intervención de otros en la toma de decisiones en materia patrimonial. Ello es evidente en lo referido a las facultades que el derecho vigente daba al cabildo de canónigos.

En lo relativo a este cuerpo colegiado, resulta llamativa la generalizada mala opinión que hay sobre él, en uno y otro lado del Atlántico al punto de llegar a proponerse derechamente su supresión desde Buenos Aires, cuyo arzobispo deja entrever las fuertes tensiones existentes entre él y el cabildo de su catedral en las expresiones peyorativas que usa para referirse a ellos. El arzobispo de Caracas, en cambio, no quiso oponerse abiertamente a ellos, por lo que, después de enviar a Roma un primer informe, que es probable que haya sido conocido y hasta consultado con el cabildo catedral, envió un segundo informe, esta vez reservado, en el que se quejaba abiertamente del cabildo catedralicio.

Hay temas que preocupan a diversos episcopados, pero la apreciación que tienen de ellos es diversa, condicionada por las realidades locales que están experimentando, lo que incide en las propuestas que hacen para solucionar los problemas que detectan, las que, en ocasiones, son hasta contradictorias. Es lo que sucede, por ejemplo, con la provisión de los beneficios, instrumento éste que constituye la columna vertebral del régimen patrimonial eclesiástico: mientras desde Quito se denuncia un relajamiento en la ley de los concursos para proveerlos y se postula mantenerla en su primer rigor, desde Durango, en México, al tiempo que se constataba que dicha práctica no estaba vigente por las dificultades que experimentaba aquella Iglesia particular, se pedía que simplemente se eliminara. 
Reformas al régimen patrimonial de la Iglesia Católica sugeridas desde España...

No siempre, sin embargo, las soluciones que sugieren son diferentes para el mismo problema, pues las hay que coinciden no sólo en la identificación del problema, sino también en la solución. Es lo que sucede con las distribuciones que les correspondía recibir a los canónigos que asistían al coro, esto es, los dineros que les correspondían por el cumplimiento de esta parte importante de sus tareas como era la de solemnizar la liturgia. Desde España se denunciaban los fraudes que se cometían, permitiendo que canónigos que no asistían al coro recibieran no obstante dichas sumas; y desde Caracas el arzobispo, en su postulatum reservado simplemente reconocía que había catedrales donde dicha asistencia estaba en el más lamentable abandono, confesando que era uno de los casos más difíciles de remediar por la autoridad episcopal. Detectado un mismo problema, la sugerencia de solución es la misma: que recibieran esas sumas de dinero sólo los que asistieran, propuesta que fue la que finalmente acogió el Código, agregando medidas para controlar efectivamente la asistencia al coro.

Sin perjuicio de que hay problemas que son comunes a las iglesias españolas e hispanoamericanas, hay también algunos problemas que son particulares de algunas de ellas. Es lo que sucede, por ejemplo, en el arzobispado de Buenos Aires con el arancel eclesiástico, es decir, con la tabla de los dineros que los fieles debían sufragar por las actividades espirituales o administrativas realizadas por la Iglesia en beneficio de ellos. La vigencia del mismo era para toda la provincia eclesiástica, pero desde Buenos Aires se pedía que el arancel fuere fijado por cada obispo para su diócesis, puesto que las realidades de los católicos de los diversos obispados de la arquidiócesis no era la misma, lo que dificultaba la aplicación de un mismo arancel a realidades locales muy diversas. O la propuesta hecha desde Santiago de Chile en relación con la dote de las religiosas, sugiriendo que las mismas fueran recibidas bajo contrato cuyo contenido detallaba, lo que hacía para prevenir cuestiones de suyo enojosas y que, con menoscabo de la paz y del decoro de las comunidades religiosas, pudieren llevarse a los tribunales civiles.

Desde una perspectiva meramente formal, por lo general las propuestas son hechas sin mayor insistencia, son meramente propositivas, sin que se advierta, en principio, un orden de prioridad entre ellas; hay empero, ocasiones en las que es posible advertir el mayor empeño que los prelados ponen en la propuesta que están haciendo, lo que ocurre con las expresiones literarias que utilizan al hacerla; es lo que sucede, por ejemplo, con los metropolitanos españoles cuando escribían en sus postulata que "convendría muchísimo" que la doctrina acerca del mutuo y de los intereses fuere expuesta más clara y precisamente; o cuando el arzobispo de Santiago de Chile decía que sería "completamente conveniente" que el código canónico sancionara los principios y las reglas que atañían a las personas jurídicas eclesiásticas, para lo que sugería los temas que debían ser abordados por los cánones, los que completaban con la traducción al latín de algunos artículos del Código Civil de Chile (1856). 
Esta última circunstancia me permite una nueva constatación: hay ocasiones, como la que acabo de señalar de las personas jurídicas, en las que los prelados sugieren específicamente los temas que debían abordarse en la materia precisa que les interesaba: cuando el arzobispo de Santiago sugería que se regulare lo relativo a las personas jurídica eclesiásticas no se limitaba a sugerir que el futuro Código contuviere cánones al respecto, sino que especificaba aquellos aspectos del instituto que entendía que debían estar regulados por los cánones: determinar cuáles serían los derechos de estas personas, qué facultades, qué obligaciones serían propios y peculiares de las personas que las representaban, y en general el régimen de éstas; además, debía indicarse el modo por el cual estas personas se extinguirían y lo que debía hacerse cuando sus constituciones nada hubiesen dispuesto acerca de los bienes de las extintas. Con todo, si bien se especificaban las materias a ser tratadas, nada se decía de los contenidos específicos de esas materias: se pedía que se regularan los derechos y facultades de las personas jurídicas eclesiásticas, pero nada se insinuaba acerca de cuáles serían esos derechos y cuáles esas facultades, eso debían definirlo los codificadores.

Casos hay, sin embargo, en que los prelados no sólo sugieren una materia a tratar, sino que proponen el específico contenido que ellos entienden que debía tener el futuro Código: es lo que hace el arzobispo de Guatemala cuando se preguntaba si no sería conveniente establecer en la ley canónica una noción más legítima del delito de usura, sugiriendo él mismo dicho concepto: "delito por el cual alguien que abusa de la ignorancia de otro o de su necesidad le exige mayores intereses de dinero que la ley o la costumbre permite".

Este concepto me permite abordar otro aspecto de estos postulata episcoporum: la denuncia de los abusos que se advierten detrás de ellos, abusos que, en ocasiones, como la de este concepto de usura, son protagonizados por personas laicas, puesto que son laicos los que exigían mayores intereses de dinero por sobre la ley o la costumbre, abusando de la ignorancia o la necesidad de otros. Pero los abusos que se advierten detrás de algunas propuestas provenían también de los Estados: es lo que sucede cuando el arzobispo de Burgos pedía que a todos los obispos se les concediere la facultad de enmendar y de retener, bajo las condiciones definidas por la Santa Sede, los bienes eclesiásticos tomados por los gobiernos; lo que se ve detrás de esta propuesta es uno de los mayores problemas que debió enfrentar la Iglesia durante la segunda mitad del siglo XIX, tanto en España como en la América hispana, como fue la decisión de algunos gobiernos, especialmente anticlericales, de intervenir en los bienes eclesiásticos, apropiándose de parte no menor de ellos, lo que, en general, puede englobarse en las llamadas políticas desamortizadoras. Los acuerdos sobre estas materias, sin embargo, y las conversaciones con los gobiernos, eran conducidas siempre desde Roma y ello solía ocurrir con la firma de concordatos, en los cuales esta materia era expresamente abordada. 
Reformas al régimen patrimonial de la Iglesia Católica sugeridas desde España...

Pero los abusos e, incluso, fraudes a los que se trata de poner atajo con las propuestas episcopales provenían también de los clérigos, porque eso es lo que está detrás de la sugerencia de que los canónigos sólo reciban parte de sus emolumentos por la asistencia efectiva al coro, lo que se sugería desde España "para evitar completamente los fraudes". Y son también abusos, esta vez de las órdenes mendicantes, los que están detrás de la propuesta del obispo chileno de San Carlos de Ancud cuando pedía derechamente que se suprimiere a las órdenes mendicantes el privilegio de colectar limosnas sin permiso del obispo diocesano, puesto que "son muchos y graves los abusos a que se presta esta excepción" (Commissione Codice Diritto Canonico, s.f.n).

No sólo abusos son los que motivan algunas de estas propuestas, sino también algunas carencias que se advierten en las iglesias particulares, como ocurre cuando el arzobispo de Tarragona sugería que se diera a los prelados la posibilidad de imponer algún tributo con el que subvenir a algunas necesidades de la diócesis, como la construcción de una casa piadosa donde los sacerdotes llegados a la vejez o por enfermedad pudieren pasar una vida en paz y tranquila, carencia que llevaba a los metropolitanos españoles a sugerir que había que esforzarse para crear asociaciones de auxilio mutuo, por ejemplo, montes de piedad, en las diócesis en las que no hubiese establecido nada similar, para que hubiere una subsistencia segura para los clérigos enfermos y de edad avanzada.

Como he dicho, en algunos casos las sugerencias de los prelados son coincidentes, hay identidad de problema y de propuesta de solución, pero en otros la propuesta es del todo original, al tiempo que es expresión de la mentalidad de la época, que no logra todavía desprenderse de viejor resabios estamentales: los metropolitanos españoles sugerían que sería muy conveniente que se otorgaren las máximas facilidades para la creación de alguna congregación de varones con votos simples, que se asignare al servicio de los sacerdotes. Y serían estas entidades las que asegurarían el sustento de los sacerdotes.

En algunas propuestas aparecen mencionadas algunas fuentes del derecho canónico. Los prelados las mencionan, cuando lo hacen, con fines diversos: en ocasiones lo hacen para pedir que se insista en su aplicación, cuando las normas, de hecho, no se aplicaban en su tenor original, lo que hacía el arzobispo de Quito cuando pedía que se mantuviese en su primer rigor la ley de concurso, fijada originalmente en Trento, con todas las reglas, circunstancias y previsiones del derecho, para la provisión de beneficios, así como las exigencias referidas a la privación, resignación y permutación de los mismos. Otras veces, se pedía que una norma canónica particular se generalizara para toda la Iglesia, lo que hacía el arzobispo de Antequera, en México, quien, invocando el Tercer Concilio Mexicano (1585), pedía que se prohibiere que las contribuciones de las misas fueren enviadas a otra parte por las congregaciones más recientes sin la venia del obispo, pues el Concilio había dispuesto a todas las 
personas a cuyo cargo estaba el hacer decir misas, que no enviasen ni la celebración de misas ni las limosnas que se habían dado por ellas para que se dijeran fuera de la diócesis, so pena de excomunión mayor latae sententiae.

Y no faltaron algunas propuestas cuyo origen está en la caridad que es preciso tener para con algunas personas, que hace sensible ante ciertas carencias y suscita la inquietud para que el derecho proporcionare la solución técnica adecuada: desde Quito se pedía que del mejor modo que se pudiere, se proveyere en aquellas cosas que son para el decoro y sustento de los religiosos que salieren de los claustros, renunciados o dispensados, bien de votos simples, bien de votos solemnes. Preocupación que era compartida por el arzobispo de Tarragona, quien pedía que se determinare a qué debía atenerse el ordinario de una orden o congregación para que, en lo tocante a los religiosos expulsados o secularizados, se evitare, en la medida de lo posible, "aquella triste y como desesperada condición en la que no es raro se encuentren cuando están en tal estado" (Commissione Codice di Diritto Canonico, s.f.i.).

Una mirada de conjunto sobre todas estas propuestas, permite hacerse un cuadro realista de los problemas que debían enfrentar las iglesias en España e hispanoamérica en materia patrimonial. Algunos de ellos ellos eran producto de la evolución de los tiempos, los que originaban cambios que daban lugar a situaciones nuevas que incidían de lleno en el patrimonio eclesial: el arzobispo de Tarragona se hacía cargo de un problema que aquejaba a las dotes de los beneficios que se establecían en su tiempo, dotes que consistían mayoritariamente en títulos del Estado o en valores públicos, cuyas rentas estaban notablemente disminuidas, lo que hacía que algunos beneficios y también algunas fundaciones se convirtieran en incongruos, con el consiguiente problema de tener que suspender su provisión. Otras veces los problemas eran el producto de las mezquindades de los gobiernos y de los hombres, como las usurpaciones de bienes eclesiásticos o los fraudes de los canónigos a los que me he referido poco antes. No era, empero, tiempo de quejarse, sino que se presentaba la ocasión para intentar superarlos con soluciones realistas y, en ocasiones, provocadoras. Los arzobispos estuvieron a la altura y cumplieron la tarea que se les encomendaba haciendo propuestas que, en opinión de ellos, facilitarían la superación de las deficiencias que advertían.

¿Cuál fue el destino de ellas? Algunas de las soluciones sugeridas desde España y América Hispana tuvieron eco en el Código. Cuando digo que la norma codicial finalmente aprobada coincide con las propuestas sugeridas desde España y América no digo, sin embargo, que dichas sugerencias hayan sido las motivadoras de la respuesta dada por el Código al problema. No cabe duda que dichos postulata han sido tenidos en cuenta, pero preciso es tener presente que, por una parte, se trataba a veces, de un problema experimentado por otras iglesias particulares, $y$, por otra, que las soluciones sugeridas coincidieran con las arribadas a Roma desde otros arzobispados amén de que estuviesen también en la mente de los codificadores. 
Reformas al régimen patrimonial de la Iglesia Católica sugeridas desde España...

Ocasiones hay en que la inquietud planteada por algunos prelados tuvo eco en el Código y debidamente regulada, pero con una solución, a veces más amplia que la sugerida por los episcopados, con lo que la inquietud quedaba atendida y satisfecha en el Codex; a veces, en cambio, la inquietud tenía eco en el Código, pero la solución codicial fue más restringida que la sugerida episcopalmente, con lo que estos se veían sólo parcialmente satisfechas: es lo que sucedió, por ejemplo, con los cánones que el Código dedicó a las personas jurídicas, que sólo recogieron en parte las particularidades propuestas desde Chile.

Otras propuestas simplemente no fueron acogidas, por ejemplo, la sugerencia del arzobispo burgalés de que, en materia de arriendo de bienes eclesiásticos, se permitiere a los obispos arrendarlos sin límite de tiempo. No quiero con ello decir que tales sugerencias no fueran tomadas en cuenta, pues, todas ellas fueron conocidas por los codificadores, simplemente fueron dejadas de lado. Con todo, algunas de estas que no tuvieron mayor suceso en el Codex luris Canonici (1917), originadas en problemas existentes al comenzar el siglo, problemas que ni desaparecieron ni encontraron adecuada respuesta en dicho Código, fueran retomadas y reformuladas en el Concilio Vaticano II encontrando finalmente una adecuada y moderna formulación en el Código en actual vigencia, como el agudo problema de la sustentación del clero, para lo cual el viejo sistema beneficial ya se mostraba del todo insuficiente.

En fin, a lo largo de estas consideraciones he intentado mostrar tan solo una página de la historia del derecho de la Iglesia, algunos de cuyos ecos se advierten aún hoy en los cánones vigentes, página que se inserta en esa bimilenaria historia de la Iglesia que ha discurrido y sigue discurriendo entre las persecuciones de los hombres y los consuelos de Dios.

\section{Reconocimientos}

Este artículo forma parte del proyecto de investigación Fondo Nacional de Desarrollo Científico y Tecnológico (FONDECYT) Regular 1160298 del que el autor es investigador responsable.

\section{Referencias Bibliográficas}

Alonso Lobo, A., Miguélez Domínguez, L., y Alonso Morán, S. (1963). Comentarios al Código de Derecho Canónico: cánones 682-1321 (Vol. 2). Madrid: Biblioteca de Autores Cristianos.

Alonso Morán, S., Cabreros de Anta, M. (1964). Comentarios al Código de Derecho Canónico: cánones 1322-1998 (Vol. 3). Madrid: Biblioteca de Autores Cristianos. 
Benedicto XV. Vaticano II. Dioecesis N. Translationis missarum. 19 de febrero de 1921. Acta Apostolicae Sedis, 13, 228-230. Recuperado de https://bit.ly/3HuRJ19

Cabreros de Anta, M., Alonso Lobo, A. y Alonso Morán, S. (1963) Comentarios al Código de Derecho Canónico: cánones 1-681 (Vol. 1). Madrid: Biblioteca de Autores Cristianos.

Cardenal A. M. Panebianco. Vaticano II. Ex S. Poenitentiaria Apostolica, Facultates regularibus in Italia violentia suppressis concessae aut declaratae. 18 de abril 1867. Acta Sanctae Sedis, 3, 151-156. Recuperado de https://bit.ly/3blvzK3

Cardenal Merry del Val. Vaticano II. Litterae circulares ad omnes Episcopos pro Ecclesiae legibus in unum redigendis. 25 de marzo 1904. Acta Sanctae Sedis, 36, 604-605. Recuperado de https://bit.ly/3mJpuSh

Cardenal Scipione Tecchi. Vaticano II. Sacra congregatio consistorialis.20 de agosto de1910. Acta Apostolicae Sedis, 2 636-648. https://bit.ly/3BYlbst

Circa títulos sacrae ordinationis. 21 de junio 1879. Acta Sanctae Sedis, 12, 569-576. Recuperado de https://bit.ly/3EL47Yv

Code Civil des Français. Impresora Imperial, París, 03 de marzo de 1804. Recuperado de https://bit.ly/3cgalmT

Codex luris Canonici: Pii X Pontificis Maximi iussu Digestus, Benedicti Papae XV auctoritate promulgatus. Prafatione, fontium annotatione et indice analitico-alphabetico ab Emo. Petro card. Gasparri auctus. (1917). Romae: Typis Polyglotis Vaticanis. Recuperado de https://bit.ly/3Cjenpf

Código Civil. Diario Oficial de la República de Chile, Santiago, Chile, 14 de diciembre de 1855. Recuperado de http://bcn.cl/2lfdd

Código de Derecho Canónico. Palacio del Vaticano, Roma, 25 enero 1983. Recuperado de https://bit.ly/30nl4cF

Commissione Codice di Diritto Canonico. (s.f.a). Postulata del arzobispo de Burgos. Archivio Segreto Vaticano, scatola, 84.

Commissione Codice di Diritto Canonico. (s.f.b). Postulata del arzobispo de Buenos Aires. Archivio Segreto Vaticano, scatola 96.

Commissione Codice di Diritto Canonico. (s.f.c). Postulata del arzobispo de Durango, México. Archivio Segreto Vaticano, scatola 96.

Commissione Codice di Diritto Canonico. (s.f.d). Postulata del arzobispo de Guatemala. Archivio Segreto Vaticano, scatola 96.

Commissione Codice di Diritto Canonico. (s.f.e). Postulata del arzobispo de Lima. Archivio Segreto Vaticano. Commissione Codice di. Diritto Canonico, scatola 96. 
Reformas al régimen patrimonial de la Iglesia Católica sugeridas desde España...

Commissione Codice di Diritto Canonico. (s.f.f). Postulata del arzobispo de Michoacán, México. Archivio Segreto Vaticano, scatola 96.

Commissione Codice di Diritto Canonico. (s.f.g). Postulata del arzobispo de Quito. Archivio Segreto Vaticano, scatola 96.

Commissione Codice di Diritto Canonico. (s.f.h). Postulata del arzobispo de Santiago de Chile. Archivio Segreto Vaticano, scatola 96.

Commissione Codice di Diritto Canonico. (s.f.i). Postulata del arzobispo de Tarragona. Archivio Segreto Vaticano, scatola 96.

Commissione Codice di Diritto Canonico. (s.f.j). Postulata de los arzobispos de Antequera, México. Archivio Segreto Vaticano, scatola 84.

Commissione Codice Diritto Canonico. (s.f.k). Postulata de los arzobispos de Brasil, Archivio Segreto Vaticano, scatola 96.

Commissione Codice Diritto Canonico. (s.f.l). Postulata de los metropolitanos españoles. Archivio Segreto Vaticano, scatola 84.

Commissione Codice Diritto Canonico. (s.f.m). Postulata del obispo de Nicaragua. Archivio Segreto Vaticano, scatola 96.

Commissione Codice Diritto Canonico. (s.f.n). Postulata del obispo de San Carlos de Ancud, Chile. Archivio Segreto Vaticano, scatola 96.

Commissione Codice Diritto Canonico. (s.f.ñ). Postulata reservados del arzobispo de Caracas. Archivio Segreto Vaticano, scatola 96.

Donoso Vivanco, J. (1848). Instituciones de derecho canónico americano (Vol. 1). Valparaíso: Imprenta y Librería del Mercurio. http://bit.ly/3vky6mk

Donoso Vivanco, J. (1849). Instituciones de derecho canónico americano (Vol. 2). Valparaíso: Imprenta y Librería del Mercurio. http://bit.ly/3vky6mk

Esquivel, H. D. (1928). Régimen eclesiástico argentino. Buenos Aires: Jesús Menéndez.

García Barberena, T. (1964) Comentarios al Código de Derecho Canónico: cánones 19992414 (Vol. 4). Madrid: Biblioteca de Autores Cristianos.

Gómez Salazar, F. (1883). Instituciones de derecho canónico (2a ed., Vol. 3). León: Imprenta de Alejandro Gómez Fuentenebro. https://bit.ly/3csNqVj

Iglesia Católica. (1563). Obispos y Cardenales. Decreto sobre la Reforma. En Concilio de Trento (Ses. 24). Recuperado de https://bit.ly/2YVDoJE 
Iglesia Católica, Concilium Plenarium Americae Latinae. (1906). Actas y decretos del concilio plenario de la américa Latina, Celebrado en Roma el año del Señor de MDCCCXCIX: traducción oficial. Roma: Tipografía Vaticana.

Martínez Ferrer, L. (Ed.). (2009). Decretos del Concilio Tercero Provincial Mexicano (1585). Zamora, MIC: El Colegio de Michoacán.

Pio X. Vaticano II. De Ecclesiae legibus in unum redigendis. 14 abril de 1904. Acta Sanctae Sedis, 36, 549-551. Recuperado de https://bit.ly/3mJpuSh

Salinas Araneda, C. (2008). El primer aporte de los obispos chilenos a la codificación del derecho canónico de 1917: los postulata del obispo de Ancud, Ramón Ángel Jara. Boletín de la Academia Chilena de la Historia, 1(117), 161-189. https://bit.ly/3qQGUNc

Salinas Araneda, C. (2009). La persona jurídica en las propuestas de los obispos chilenos a la codificación del Derecho Canónico de 1917. Revista de Derecho (Coquimbo), 16(1), 135-166. doi: 10.22199/s07189753.2009.0001.00005

Vetulani, A. (1942). Codex luris Canonici. En R. Naz (Ed.), Dictionnaire de Droit Canonique (Vol. 3, pp. 909-935). Paris: Letouzey.

\section{Para citar este artículo bajo Norma APA 6a ed.}

Salinas Araneda, C. (2021). Reformas al régimen patrimonial de la Iglesia Católica sugeridas desde España y Latinoamérica al iniciarse la codificación del derecho canónico de 1917. Revista de Derecho (Coquimbo. En línea), 28, e3364. https://doi.org/10.22199/issn.0718-9753-2021-0022

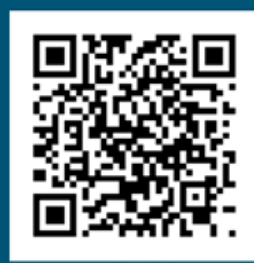

DOI

\section{(cc) BY}

Este es un artículo de acceso abierto, bajo licencia Creative Commons BY 4.0. 